\title{
LEVEL II SCOUR ANALYSIS FOR BRIDGE 8 (BARTTH00020008) on TOWN HIGHWAY 2, crossing ROARING BROOK, BARTON, VERMONT
}

U.S. Geological Survey Open-File Report 96-404

Prepared in cooperation with

VERMONT AGENCY OF TRANSPORTATION and

FEDERAL HIGHWAY ADMINISTRATION 


\section{LEVEL II SCOUR ANALYSIS FOR BRIDGE 8 (BARTTH00020008) on TOWN HIGHWAY 2, crossing ROARING BROOK, BARTON, VERMONT}

By Erick M. Boehmler and Michael A. Ivanoff

\section{U.S. Geological Survey Open-File Report 96-404}

Prepared in cooperation with

VERMONT AGENCY OF TRANSPORTATION and

FEDERAL HIGHWAY ADMINISTRATION 


\title{
U.S. DEPARTMENT OF THE INTERIOR BRUCE BABBITT, Secretary
}

\author{
U.S. GEOLOGICAL SURVEY \\ Gordon P. Eaton, Director
}

For additional information write to:

District Chief

U.S. Geological Survey 361 Commerce Way

Pembroke, NH 03275-3718
Copies of this report may be purchased from:

U.S. Geological Survey Earth Science Information Center Open-File Reports Section Box 25286, MS 517 Federal Center

Denver, CO 80225 


\section{CONTENTS}

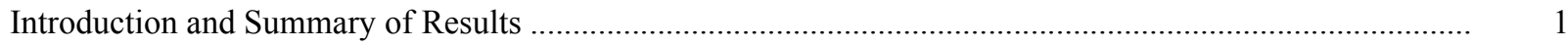

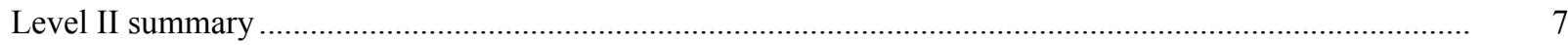

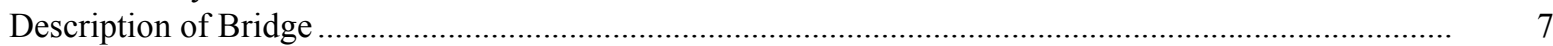

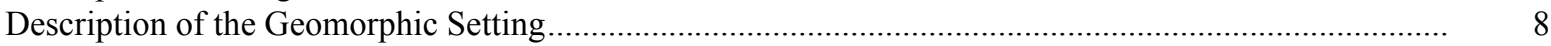

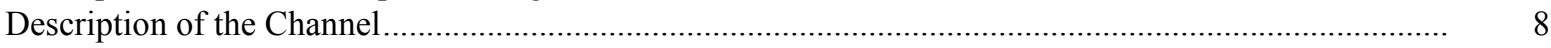

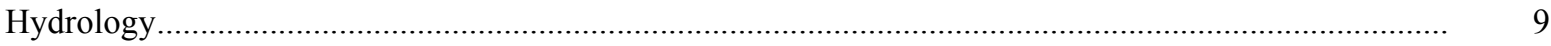

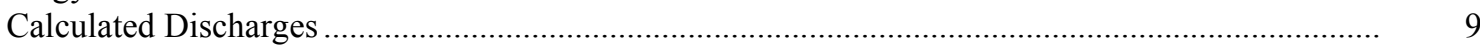

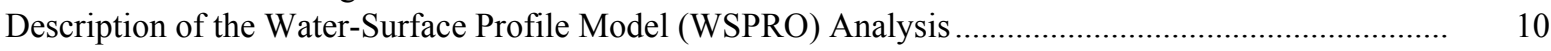

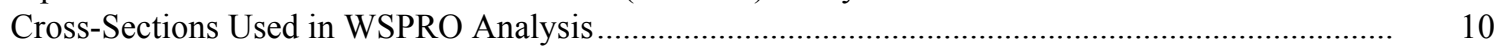

Data and Assumptions Used in WSPRO Model ...................................................................... 11

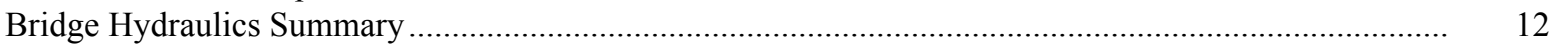

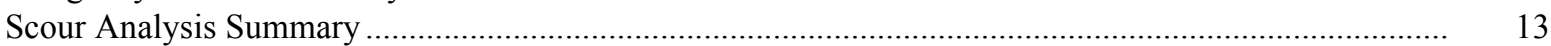

Special Conditions or Assumptions Made in Scour Analysis ...................................................... 13

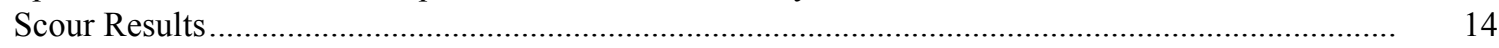

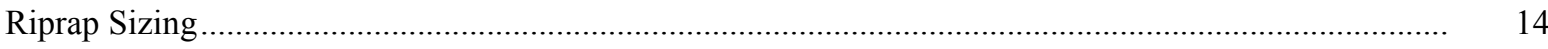

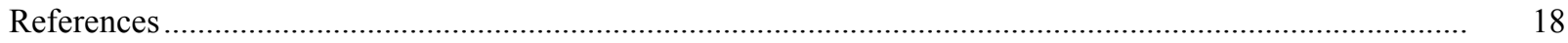

Appendixes:

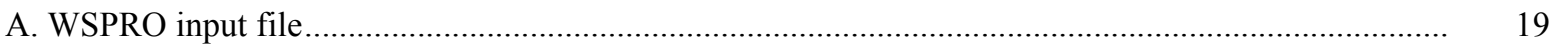

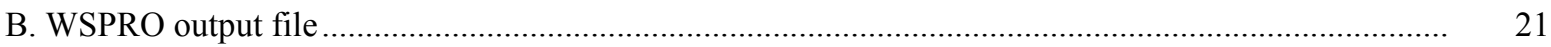

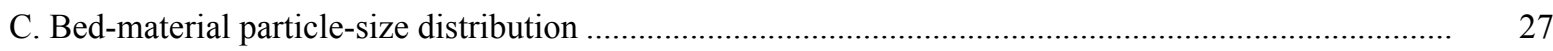

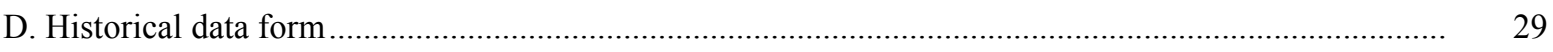

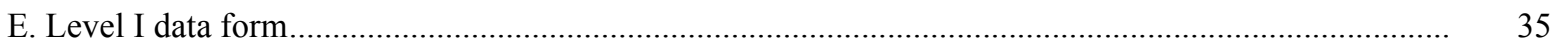

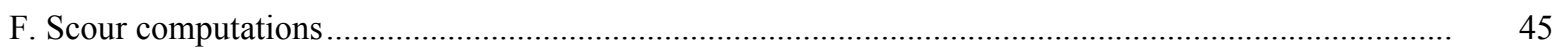

\section{FIGURES}

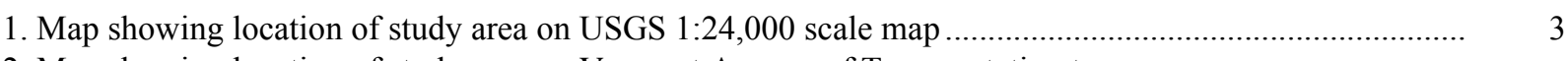

2. Map showing location of study area on Vermont Agency of Transportation town
highway map

3. Structure BARTTH00020008 viewed from upstream (October 18, 1994) ............................................. 5

4. Downstream channel viewed from structure BARTTH00020008 (October 18, 1994)........................... 5

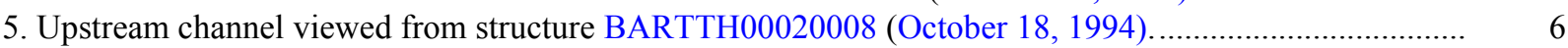

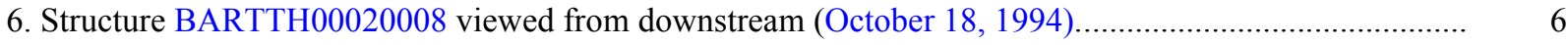

7. Water-surface profiles for the 100- and 500-year discharges at structure

BARTTH00020008 on Town Highway 2, crossing Roaring Brook,

Barton, Vermont.

8. Scour elevations for the 100- and 500-year discharges at structure

BARTTH00020008 on Town Highway 2, crossing Roaring Brook,

Barton, Vermont.

\section{TABLES}

1. Remaining footing/pile depth at abutments for the 100-year discharge at structure

BARTTH00020008 on Town Highway 2, crossing Roaring Brook,

Barton, Vermont.

2. Remaining footing/pile depth at abutments for the 500-year discharge at structure

BARTTH00020008 on Town Highway 2, crossing Roaring Brook,

Barton, Vermont.

5




\begin{tabular}{|c|c|c|}
\hline Multiply & By & To obtain \\
\hline \multicolumn{3}{|c|}{ Length } \\
\hline inch (in.) & 25.4 & millimeter (mm) \\
\hline foot $(\mathrm{ft})$ & 0.3048 & meter $(\mathrm{m})$ \\
\hline mile (mi) & 1.609 & kilometer (km) \\
\hline \multicolumn{3}{|c|}{ Slope } \\
\hline foot per mile ( $\mathrm{ft} / \mathrm{mi})$ & 0.1894 & meter per kilometer $(\mathrm{m} / \mathrm{km})$ \\
\hline \multicolumn{3}{|c|}{ Area } \\
\hline square mile $\left(\mathrm{mi}^{2}\right)$ & 2.590 & square kilometer $\left(\mathrm{km}^{2}\right)$ \\
\hline \multicolumn{3}{|c|}{ Volume } \\
\hline cubic foot $\left(\mathrm{ft}^{3}\right)$ & $\begin{array}{l}0.02832 \\
\text { Velocity and Flow }\end{array}$ & cubic meter $\left(\mathrm{m}^{3}\right)$ \\
\hline foot per second (ft/s) & 0.3048 & meter per second $(\mathrm{m} / \mathrm{s})$ \\
\hline cubic foot per second $\left(\mathrm{ft}^{3} / \mathrm{s}\right)$ & 0.02832 & cubic meter per second $\left(\mathrm{m}^{3} / \mathrm{s}\right)$ \\
\hline $\begin{array}{l}\text { cubic foot per second per } \\
\text { square mile } \\
{\left[\left(\mathrm{ft}^{3} / \mathrm{s}\right) / \mathrm{mi}^{2}\right]}\end{array}$ & 0.01093 & $\begin{array}{l}\text { cubic meter per } \\
\text { second per square } \\
\text { kilometer }\left[\left(\mathrm{m}^{3} / \mathrm{s}\right) / \mathrm{km}^{2}\right]\end{array}$ \\
\hline
\end{tabular}

OTHER ABBREVIATIONS

$\begin{array}{lrlr}\mathrm{BF} & \text { bank full } & \text { LWW } & \text { left wingwall } \\ \mathrm{cfs} & \text { cubic feet per second } & \text { MC } & \text { main channel } \\ \mathrm{D}_{50} & \text { median diameter of bed material } & \text { RAB } & \text { right abutment } \\ \mathrm{DS} & \text { downstream } & \text { RABUT } & \text { face of right abutment } \\ \mathrm{elev} & \text { elevation } & \text { RB } & \text { right bank } \\ \mathrm{f} / \mathrm{p} & \text { flood plain } & \text { ROB } & \text { right overbank } \\ \mathrm{ft} & \text { square feet } & \text { RWW } & \text { right wingwall } \\ \mathrm{ft} / \mathrm{ft} & \text { feet per foot } & \text { TH } & \text { town highway } \\ \mathrm{JCT} & \text { junction } & \text { UB } & \text { under bridge } \\ \mathrm{LAB} & \text { left abutment } & \text { US } & \text { upstream } \\ \mathrm{LABUT} & \text { face of left abutment } & \text { USGS } & \text { United States Geological Survey } \\ \text { LB } & \text { left bank } & \text { VTAOT Vermont Agency of Transportation } \\ \text { LOB } & \text { left overbank } & \text { WSPRO } & \text { water-surface profile model }\end{array}$

In this report, the words "right" and "left" refer to directions that would be reported by an observer facing downstream. Sea level: In this report, "sea level" refers to the National Geodetic Vertical Datum of 1929-- a geodetic datum derived from a general adjustment of the first-order level nets of the United States and Canada, formerly called Sea Level Datum of 1929.

In the appendices, the above abbreviations may be combined. For example, USLB would represent upstream left bank. 


\title{
LEVEL II SCOUR ANALYSIS FOR BRIDGE 8 (BARTTH00020008) ON TOWN HIGHWAY 2, CROSSING ROARING BROOK, BARTON, VERMONT
}

\author{
By Erick M. Boehmler and Michael A. Ivanoff
}

\section{INTRODUCTION}

This report provides the results of a detailed Level II analysis of scour potential at structure BARTTH00020008 on town highway 2 crossing Roaring Brook, Barton, Vermont (figures $1-8)$. A Level II study is a basic engineering analysis of the site, including a quantitative analysis of stream stability and scour (U.S. Department of Transportation, 1993). Results of a Level I scour investigation also are included in Appendix E of this report. A Level I investigation provides a qualitative geomorphic characterization of the study site. Information on the bridge, gleaned from VTAOT files, was compiled prior to conducting Level I and Level II analyses and can be found in Appendix D.

The site is in the New England Upland section of the New England physiographic province of North-central Vermont in the town of Barton. The 9.89- $\mathrm{mi}^{2}$ drainage area is in a predominantly rural and forested basin. In the vicinity of the study site, the banks have woody vegetation coverage except for the downstream left bank, which has a few trees and grass and brush coverage.

In the study area, Roaring Brook has an incised, sinuous channel with a slope of approximately $0.019 \mathrm{ft} / \mathrm{ft}$, an average channel top width of $35 \mathrm{ft}$ and an average channel depth of $3 \mathrm{ft}$. The predominant channel bed material is gravel/cobble $\left(\mathrm{D}_{50}\right.$ is $49.1 \mathrm{~mm}$ or $0.161 \mathrm{ft})$. The geomorphic assessment at the time of the Level I and Level II site visit on October 18, 1994 indicated that the reach was laterally unstable. A cut-bank on the downstream right bank and overall channel configuration in the valley are indications of the lateral instability at this site.

The town highway 2 crossing of Roaring Brook is a 30 -ft-long, two-lane bridge consisting of one 26-foot span concrete T-beam type superstructure (Vermont Agency of Transportation, written communication, August 4, 1994). The bridge is supported by vertical, concrete abutments. The channel is skewed approximately 15 degrees to the opening while the opening-skew-to-roadway is zero degrees. 
A scour hole $2.5 \mathrm{ft}$ deeper than the mean thalweg depth was observed near mid-channel downstream of the bridge during the Level I assessment. The only scour protection measure at the site was type-1 stone fill (less than 12 inches diameter) on the left upstream and downstream roadway embankments. Additional details describing conditions at the site are included in the Level II Summary and Appendices D and E.

Scour depths and rock rip-rap sizes were computed using the general guidelines described in Hydraulic Engineering Circular 18 (Richardson and others, 1995).

Total scour at a highway crossing is comprised of three components: 1) long-term aggradation or degradation; 2) contraction scour (due to reduction in flow area caused by a bridge) and; 3) local scour (caused by accelerated flow around piers and abutments). Total scour is the sum of the three components. Equations are available to compute scour depths for contraction and local scour and a summary of the results follows.

Contraction scour for all modelled flows ranged from 1.4 to 2.8 feet and the worst-case contraction scour occurred at the 500-year discharge. Abutment scour ranged from 8.5 to 16.5 feet and the worst-case abutment scour occurred at the 500-year discharge. Additional information on scour depths and depths to armoring are included in the section titled "Scour Results". Scoured-streambed elevations, based on the calculated scour depths, are presented in tables 1 and 2. A cross-section of the scour computed at the bridge is presented in figure 8. Scour depths were calculated assuming an infinite depth of erosive material and a homogeneous particle-size distribution.

It is generally accepted that the Froehlich equation (abutment scour) gives "excessively conservative estimates of scour depths" (Richardson and others, 1995, p. 47). Usually, computed scour depths are evaluated in combination with other information including (but not limited to) historical performance during flood events, the geomorphic stability assessment, existing scour protection measures, and the results of the hydraulic analyses. Therefore, scour depths adopted by VTAOT may differ from the computed values documented herein. 


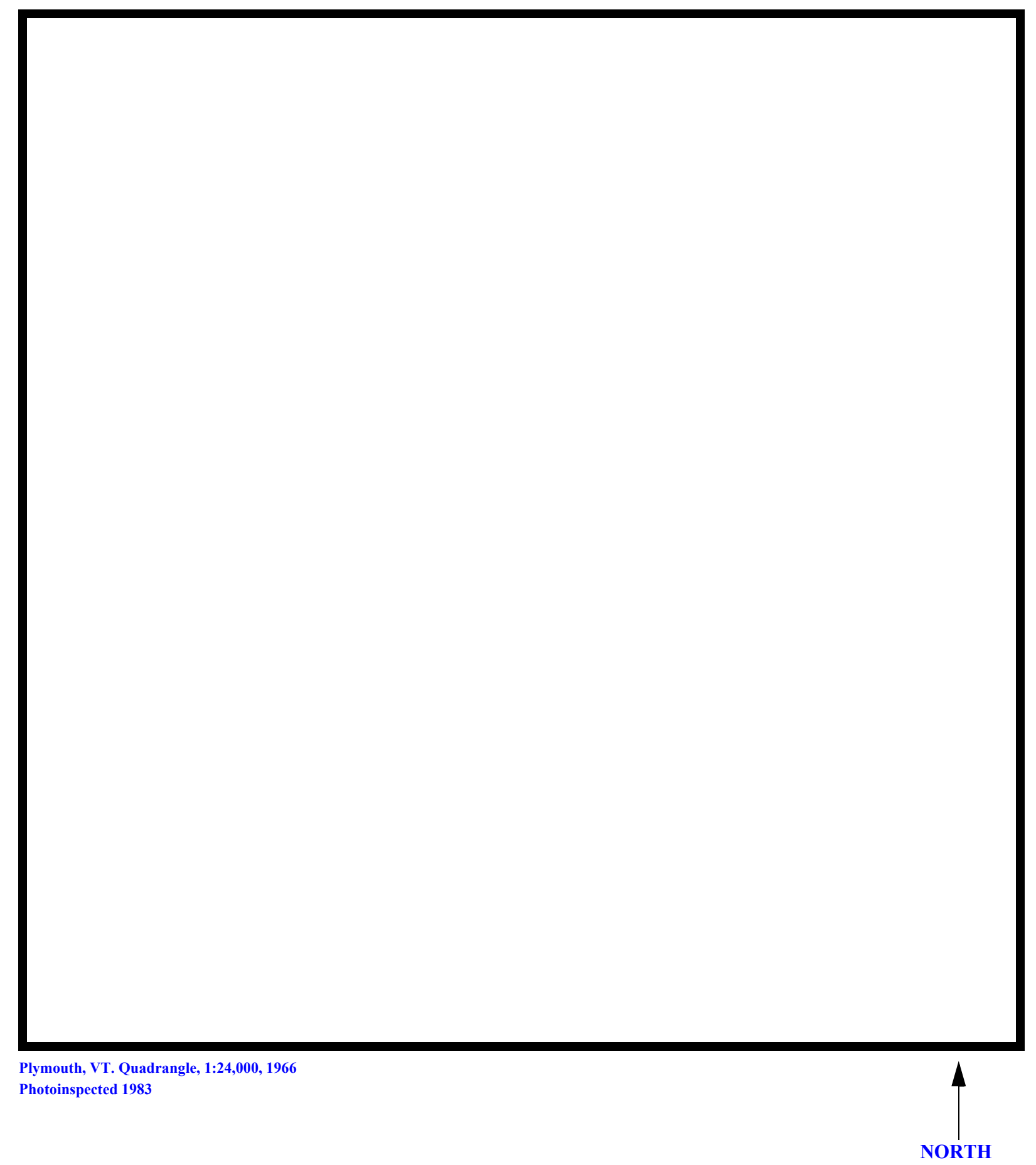

Figure 1. Location of study area on USGS 1:24,000 scale map. 
Figure 2. Location of study area on Vermont Agency of Transportation town highway map. 

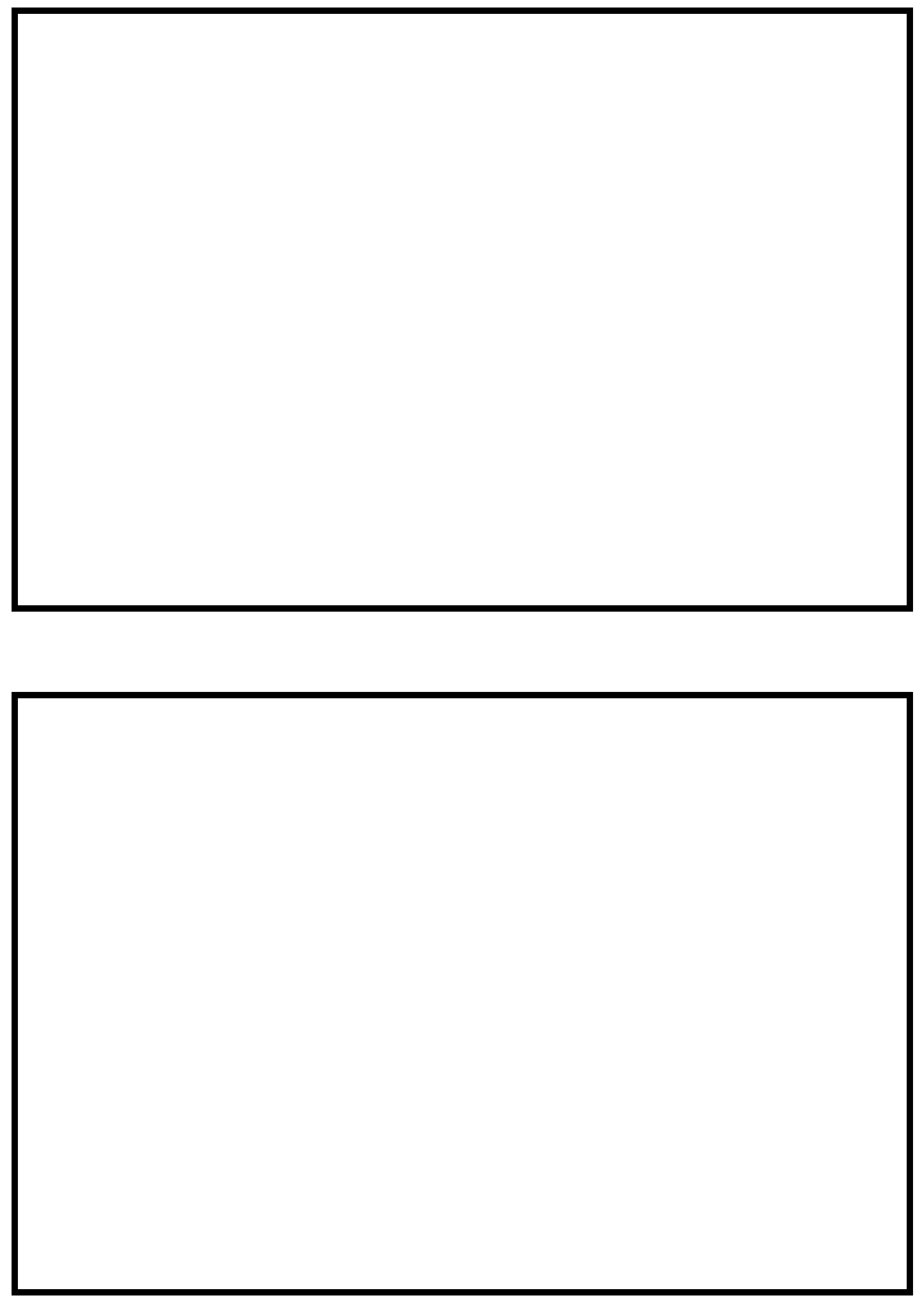

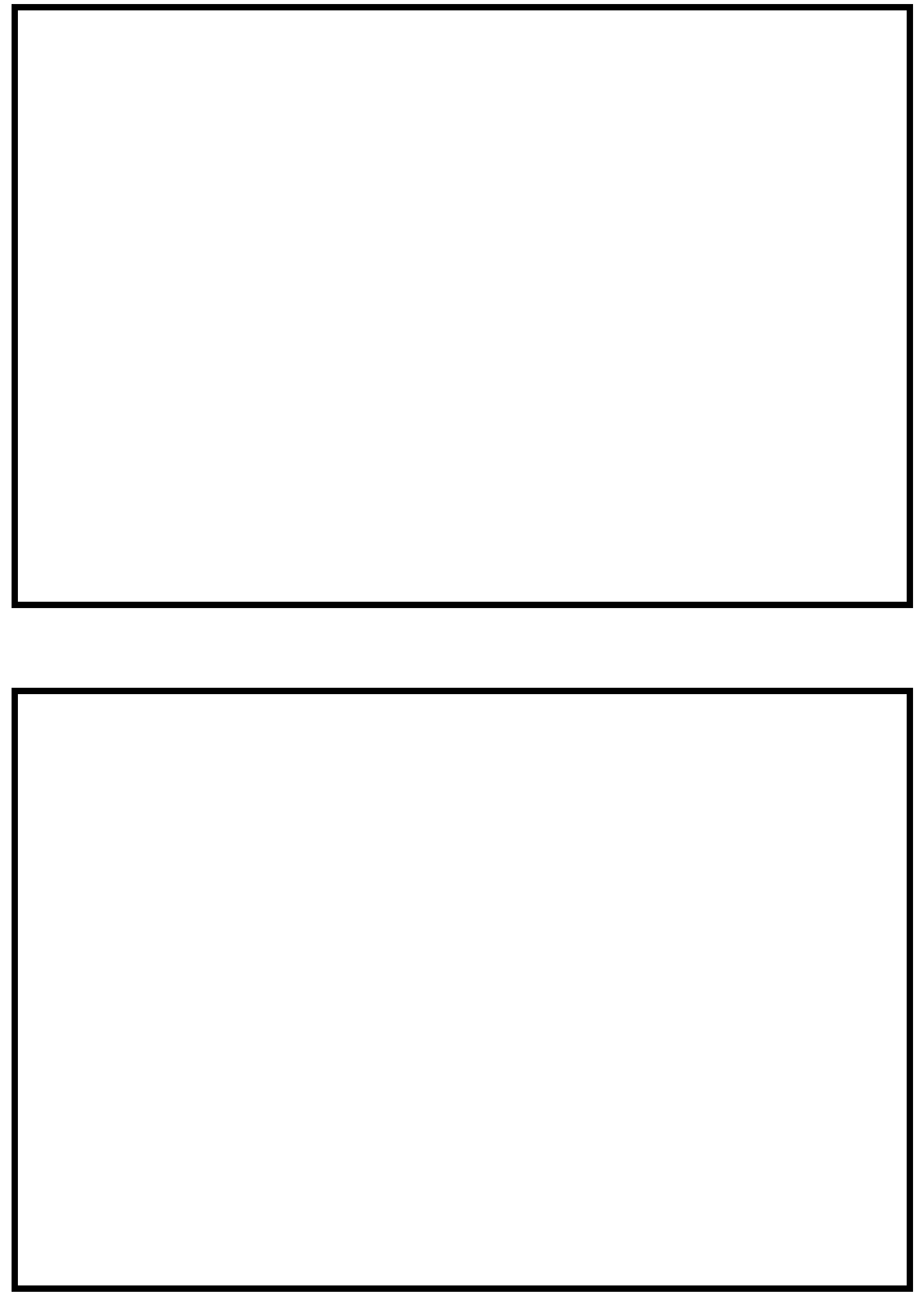


\section{LEVEL II SUMMARY}

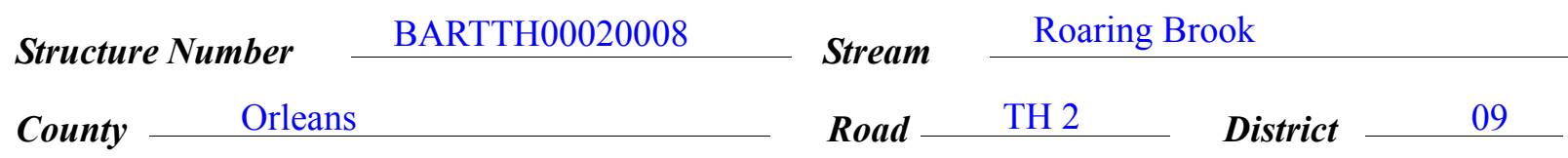

\section{Description of Bridge}

Bridge length $\stackrel{30}{ } \boldsymbol{f t} \quad$ Bridge width $\stackrel{23.6}{f t}$ Max span length $\stackrel{26}{\boldsymbol{f t}}$

Alignment of bridge to road (on curve or straight)

Abutment type

\begin{tabular}{|c|c|c|}
\hline \multirow{2}{*}{ Abutment type } & \multirow[b]{2}{*}{ Embankment type } & Sloping \\
\hline & & $10 / 18 / 94$ \\
\hline Stone fill on abutment? & $\begin{array}{l}\text { Dato af incnortinn } \\
\text { Type-1, on the left upstream and downs }\end{array}$ & tream roadway embankments. \\
\hline
\end{tabular}

On a curve

Abutments are concrete. There is a scour hole about two and a half feet deep near mid-channel
Is bridge skewed to flood flow according to There 'survey?
is a mild channel bend in the upstream reach followed by a moderate bend immediately...,
downstream of the bridge.

Debris accumulation on bridge at time of Level I or Level II site visit:

\begin{tabular}{|c|c|c|c|}
\hline & $\begin{array}{c}\text { Date of insnortion } \\
10 / 18 / 94 \\
\end{array}$ & $\begin{array}{l}\text { Percent of alommal } \\
\text { blocked inortzontatly }\end{array}$ & $\begin{array}{l}\text { Percent of } 0 \\
\text { blocked verticatty }\end{array}$ \\
\hline & $10 / 18 / 94$ & -- & -- \\
\hline
\end{tabular}

Level II

High. The channel is laterally unstable and the banks have

significant vegetation coverage near the channel.

Potential for debris

Large, apparently native, boulders scattered from right side to mid-channel downstream will Doscriho anv foaturos noar ar at the hridoo that mav, affort flow, (includo ahsorvation dato) partially block flood flow exiting the bridge as of 10/18/94. 


\section{Description of the Geomorphic Setting}

General topography The channel is located in a moderate relief valley setting configured with a steep valley wall on the USRB but moderately sloped elsewhere.

Geomorphic conditions at bridge site: downstream (DS), upstream (US)

Date of inspection $\quad 10 / 18 / 94$

DS left: $\quad$ Moderate bank slope to a more gradual, irregular overbank slope.

DS right: $\quad$ Steep bank slope to a flat overbank.

US left: $\quad$ Moderate bank slope to a gradual, irregular overbank slope.

US right: $\quad$ Moderate bank slope to steep valley wall.

\section{Description of the Channel}

\begin{tabular}{|c|c|c|c|}
\hline \multirow[b]{2}{*}{ Average top width } & \multirow[b]{2}{*}{$\stackrel{\boldsymbol{f t}}{\text { Gravel / Cobbles }}$} & \multirow[b]{2}{*}{ Average depth } & \multirow[b]{2}{*}{ Gravel/Sand ${ }^{\boldsymbol{f}}$} \\
\hline & & & \\
\hline Predominant bed ma & & \multicolumn{2}{|c|}{ Bank materim $\stackrel{\text { Sinuous and laterally }}{ }$} \\
\hline unstable with semi-a & el boundaries. & .. $\quad$. & \\
\hline
\end{tabular}

Vegetative co 1 Brush with a few trees

DS left: $\quad$ Trees

DS right: $\quad$ Trees

US left: $\quad$ Trees

US right:

$\mathrm{N}$

Do banks appear stable? On 10/18/94 a cyt-bank with slumping bank material was evident on the right bank immediately downstream of the bridge. Additionally, a land-slide type bank
date of observatton. failure was evident on the right bank about 200 feet upstream with a co-existing point bar on the left bank side.

The assessment of

10/18/94 noted large, apparently native, boulders on the right bank downstream, which partially Describe any obstructions in channel and date of observation.

block the channel at the bridge outlet. In the vicinity of these boulders, a 2.5 foot deep scour hole has developed near mid-channel. 


\title{
Hydrology
}

Drainage area $\stackrel{9.89}{\boldsymbol{m i}^{2}}$

Percentage of drainage area in physiographic provinces: (approximate)

Physiographic province/section New England / New England Upland
Percent of drainage area 100

\begin{abstract}
Is drainage area considered rural or urban?
Rural None. urbanization: None.

Describe any significant
\end{abstract}

Is there a USGS gage on the stream of interest?

USGS gage description

USGS gage number

Gage drainage area $\quad \mathrm{mi}^{2}$

USGS gage description
USGS gage number
Gage drainage area
Is there a lake/p

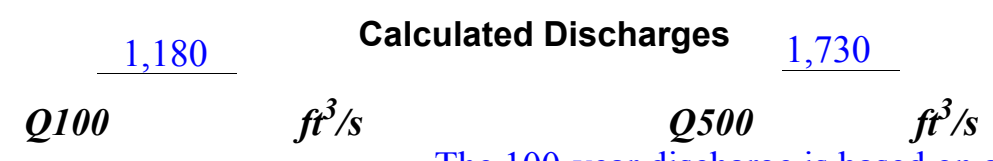

The 100-year discharge is based on a drainage area

relationship $[Q 100=1400(9.9 / 8.9)]_{0}$ with bridge number 32 in Barton, for which there were flood frequency estimates available in the VTAOT database (Written communication, VTAOT, May 4, 1995), and results from several empirical relationships (Benson, 1962; FHWA, 1983; Johnson and Tasker, 1974; Potter, 1957a \& b; Talbot, 1887). Each flood frequency curve was extrapolated to obtain the 500-year discharge. Because bridge 32 in Barton may be visually observed upstream from this site, the difference in the 100-year discharge is assumed to result primarily due to the change in area. 


\section{Description of the Water-Surface Profile Model (WSPRO) Analysis}

Datum for WSPRO analysis (USGS survey, sea level, VTAOT plans)

USGS survey

Datum tie between USGS survey and VTAOT plans

None

Description of reference marks used to determine USGS datum. $\quad$ RM1 is a chiseled " $\mathrm{X}$ "

in a chiseled square on top of the right abutment's US end (elev. $96.84 \mathrm{ft}$., arbitrary datum). RM2

is the high point of a chiseled square on top of a boulder located about 20 feet downstream of the

downstream bridge face along the right bank edge of the channel (elev. $90.71 \mathrm{ft}$., arbitrary

datum).

\section{Cross-Sections Used in WSPRO Analysis}

\begin{tabular}{|c|c|c|c|}
\hline${ }^{1}$ Cross-section & $\begin{array}{c}\text { Section } \\
\text { Reference } \\
\text { Distance } \\
\text { (SRD) in feet }\end{array}$ & $\begin{array}{c}{ }^{2} \text { Cross-section } \\
\text { development }\end{array}$ & Comments \\
\hline EXIT1 & -42 & 1 & Exit section \\
\hline FULLV & 0 & 2 & $\begin{array}{l}\text { Downstream Full-valley } \\
\text { section (Templated from } \\
\text { EXIT1) }\end{array}$ \\
\hline BRIDG & 0 & 1 & Bridge section \\
\hline RDWAY & 12 & 1 & Road Grade section \\
\hline APPR1 & 48 & 1 & Approach section \\
\hline
\end{tabular}

${ }^{1}$ For location of cross-sections see plan-view sketch included with Level I field form, Appendix E. For more detail on how cross-sections were developed see WSPRO input file. 


\section{Data and Assumptions Used in WSPRO Model}

Hydraulic analyses of the reach were done by use of the Federal Highway Administration's WSPRO step-backwater computer program (Shearman and others, 1986, and Shearman, 1990). The analyses reported herein reflect conditions existing at the site at the time of the study. Furthermore, in the development of the model it was necessary to assume no accumulation of debris or ice at the site. Results of the hydraulic model are presented in the Bridge Hydraulic Summary, Appendix B, and figure 7.

Channel roughness factors (Manning's " $\mathrm{n}$ ") used in the hydraulic model were estimated using field inspections at each cross section following the general guidelines described by Arcement and Schneider (1989). Final adjustments to the values were made during the modelling of the reach. Channel " $\mathrm{n}$ " values for the reach ranged from 0.040 to 0.055 , and the exit left overbank " $n$ " value was 0.065 .

Normal depth at the exit section (EXIT1) was assumed as the starting water surface. This depth was computed by use of the slope-conveyance method outlined in the user's manual for WSPRO (Shearman, 1990). The slope used was $0.0188 \mathrm{ft} / \mathrm{ft}$, which was estimated from surveyed channel points at and downstream of the EXIT1 section.

The surveyed approach section (APPR1) was surveyed approximately one bridge length upstream of the upstream face as recommended by Shearman and others (1986). This approach also provides a consistent method for determining scour variables.

For the 100-year discharge, WSPRO assumes critical depth at the bridge section. A supercritical model was developed for this discharge. Analyzing both the supercritical and subcritical profiles, it can be determined that the water surface profile does pass through critical depth within the bridge opening. Thus, the assumption of critical depth at the bridge is a satisfactory solution.

The 100- and 500-year discharges modeled did not result in roadway overtopping. 


\section{Bridge Hydraulics Summary}

$\begin{array}{llll}\text { Average bridge embankment elevation } & 99.6 & f t \\ \text { Average low steel elevation } & 96.2 & \boldsymbol{f t}\end{array}$

100-year discharge $\quad 1,180 \quad \mathrm{ft}^{3} / \mathrm{s}$

Water-surface elevation in bridge opening

Road overtopping? ___ N Discharge over road

$93.1 \mathrm{ft}$

Area of flow in bridge opening $\quad 100 \quad \boldsymbol{f t}^{2}$

Average velocity in bridge opening $\quad 11.9 \mathrm{ft} / \mathrm{s}$

Maximum WSPRO tube velocity at bridge $\quad 14.3 \mathrm{ft} / \mathrm{s}$

Water-surface elevation at Approach section with bridge 95.7

Water-surface elevation at Approach section without bridge $\quad 93.9$

Amount of backwater caused by bridge $\quad 1.8$ it

500-year discharge $\quad 1,730 \quad \mathrm{ft}^{3} / \mathrm{s}$

Water-surface elevation in bridge opening

Road overtopping? ___ N Discharge over road

\section{$96.2 f t$}

Area of flow in bridge opening $\quad 169 \quad \mathrm{ft}^{2}$

Average velocity in bridge opening $10.4 \mathrm{ft} / \mathrm{s}$

Maximum WSPRO tube velocity at bridge 12.2 's

Water-surface elevation at Approach section with bridge

Water-surface elevation at Approach section without bridge

Amount of backwater caused by bridge

4.5

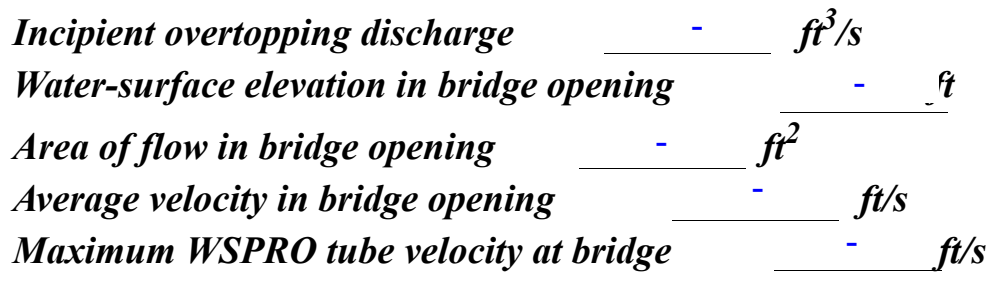

Water-surface elevation at Approach section with bridge

Water-surface elevation at Approach section without bridge Amount of backwater caused by bridge _ _ _ it
99.4

$0, \ldots / s$

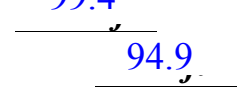




\section{Scour Analysis Summary}

\section{Special Conditions or Assumptions Made in Scour Analysis}

Scour depths were computed using the general guidelines described in Hydraulic Engineering Circular 18 (Richardson and others, 1995). Scour depths were calculated assuming an infinite depth of erosive material and a homogeneous particle-size distribution. The results of the scour analysis are presented in tables 1 and 2 and a graph of the scour depths is presented in figure 8 .

The 500-year discharge resulted in unsubmerged orifice flow. Contraction scour at bridges with orifice flow is best estimated by use of the Chang pressure-flow scour equation (oral communication, J. Sterling Jones, October 4, 1996). Therefore, contraction scour for the 500-year discharge was computed by use of the Chang equation (Richardson and others, 1995, p. 145-146). For the 100-year discharge, contraction scour was computed by use of the clear-water contraction scour equation (Richardson and others, 1995, p. 32, equation 20). For contraction scour computations using the Laursen's equation, the average depth in the contracted section (AREA/TOPWIDTH) is subtracted from the depth of flow computed by the scour equation (Y2) to determine the actual amount of scour. The results of Laursen's clear-water contraction scour for the 500-year event were also computed and can be found in appendix F. The depths to streambed armoring computed suggest the contraction scour will not be limited by armoring.

Abutment scour for each discharge modeled was computed by use of the Froehlich equation (Richardson and others, 1995, p. 48, equation 28). Variables for the Froehlich equation include the Froude number of the flow approaching the embankments, the length of the embankment blocking flow, and the depth of flow approaching the embankment less any roadway overtopping. 


\section{Scour Results}

100-yr discharge 500-yrdischarge

Incipient

Contraction scour:

(Scour depths in feet)

Main channel

Live-bed scour

Clear-water scour

Depth to armoring

Left overbank

Right overbank

Local scour:

Abutment scour

Left abutment

8.5

11.4

12.3

$16.5-$

\section{Right abutment}

Pier scour

Pier 1

Pier 2

Pier 3

Abutments:

Left abutment

Right abutment

Piers:

Pier 1

Pier 2

\section{Riprap Sizing}

overtopping

discharge

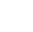




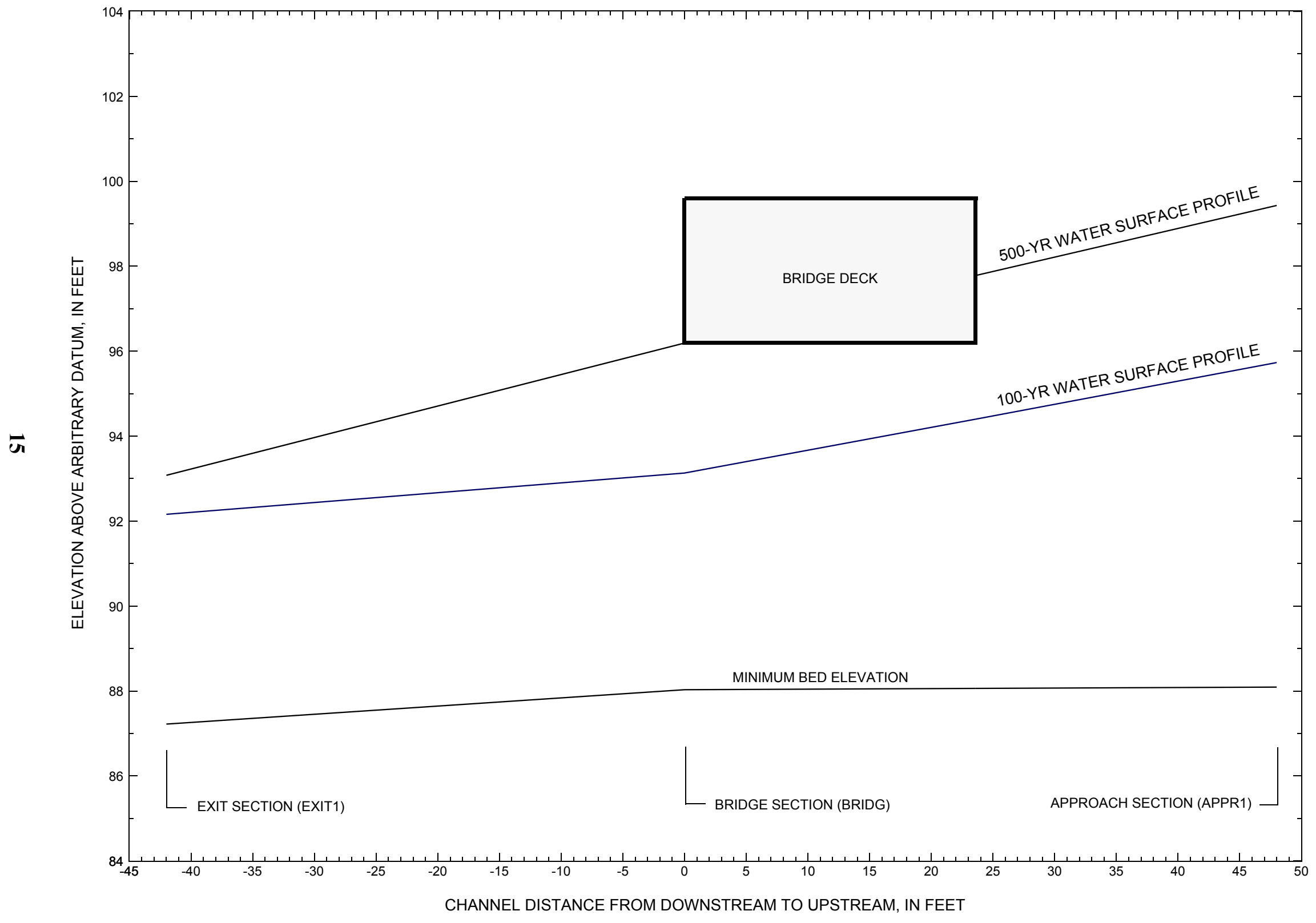

Figure 7. Water-surface profiles for the 100- and 500-yr discharges at structure BARTTH00020008 on town highway 2, crossing Roaring Brook, Barton, Vermont. 


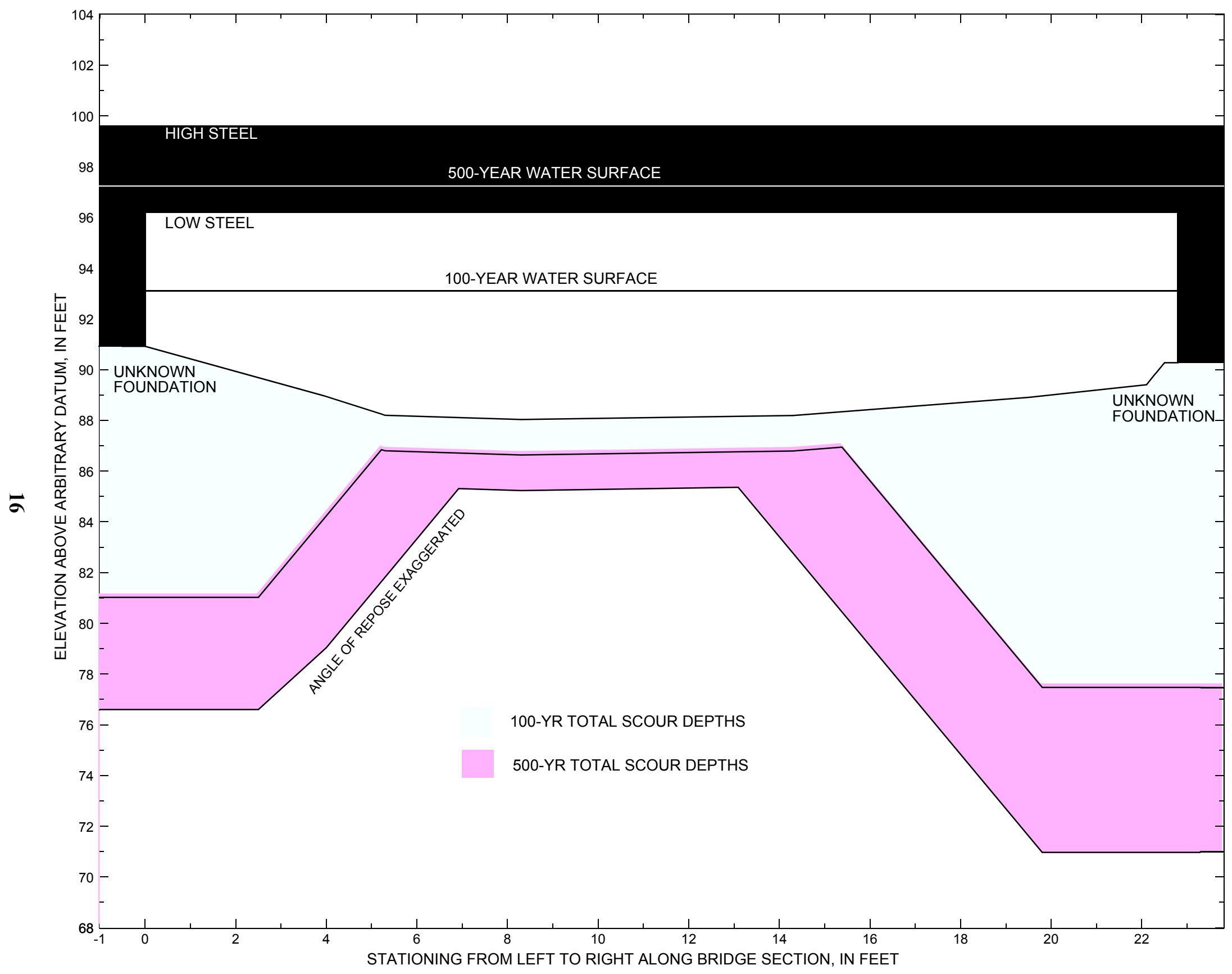

Figure 8. Scour elevations for the 100-yr and 500-yr discharges at structure BARTTH00020008 on town highway 2, crossing Roaring Brook, Barton, Vermont. 
Table 1. Remaining footing/pile depth at abutments for the 100-year discharge at structure BARTTH00020008 on Town Highway 2, crossing Roaring Brook, Barton, Vermont.

[VTAOT, Vermont Agency of Transportation; --,no data]

\begin{tabular}{|c|c|c|c|c|c|c|c|c|c|c|c|}
\hline Description & Station $^{1}$ & $\begin{array}{l}\text { VTAOT } \\
\text { minimum } \\
\text { low-chord } \\
\text { elevation } \\
\text { (feet) }\end{array}$ & $\begin{array}{c}\text { Surveyed } \\
\text { minimum } \\
\text { low-chord } \\
\text { elevation } \\
\text { (feet) }\end{array}$ & $\begin{array}{c}\text { Bottom of } \\
\text { footing } \\
\text { elevation } \\
\text { (feet) }\end{array}$ & $\begin{array}{l}\text { Channel } \\
\text { elevation at } \\
\text { abutment/ } \\
\text { pier }^{2} \\
\text { (feet) }\end{array}$ & $\begin{array}{l}\text { Contraction } \\
\text { scour depth } \\
\text { (feet) }\end{array}$ & $\begin{array}{l}\text { Abutment } \\
\text { scour } \\
\text { depth } \\
\text { (feet) }\end{array}$ & $\begin{array}{l}\text { Pier } \\
\text { scour } \\
\text { depth } \\
\text { (feet) }\end{array}$ & $\begin{array}{l}\text { Depth of } \\
\text { total scour } \\
\text { (feet) }\end{array}$ & $\begin{array}{c}\text { Elevation of } \\
\text { scour }^{2} \\
\text { (feet) }\end{array}$ & $\begin{array}{c}\text { Remaining } \\
\text { footing/pile } \\
\text { depth } \\
\text { (feet) }\end{array}$ \\
\hline \multicolumn{12}{|c|}{100 -yr. discharge is 1,180 cubic-feet per second } \\
\hline Left abutment & 0.0 & -- & 96.2 & -- & 90.9 & 1.4 & 8.5 & -- & 9.9 & 81.0 & -- \\
\hline Right abutment & 22.8 & -- & 96.2 & -- & 90.3 & 1.4 & 12.3 & -- & 13.7 & 76.6 & -- \\
\hline
\end{tabular}

${ }^{1}$. Measured along the face of the most constricting side of the bridge.

2. Arbitrary datum for this study.

Table 2. Remaining footing/pile depth at abutments for the 500-year discharge at structure BARTTH00020008 on Town Highway 2, crossing Roaring Brook, Barton, Vermont. [VTAOT, Vermont Agency of Transportation; --, no data]

\begin{tabular}{|c|c|c|c|c|c|c|c|c|c|c|c|}
\hline Description & Station $^{1}$ & $\begin{array}{l}\text { VTAOT } \\
\text { minimum } \\
\text { low-chord } \\
\text { elevation } \\
\text { (feet) }\end{array}$ & $\begin{array}{c}\text { Surveyed } \\
\text { minimum } \\
\text { low-chord } \\
\text { elevation } \\
\text { (feet) }\end{array}$ & $\begin{array}{c}\text { Bottom of } \\
\text { footing } \\
\text { elevation } \\
\text { (feet) }\end{array}$ & $\begin{array}{l}\text { Channel } \\
\text { elevation at } \\
\text { abutment/ } \\
\text { pier }^{2} \\
\text { (feet) }\end{array}$ & $\begin{array}{c}\text { Contraction } \\
\text { scour depth } \\
\text { (feet) }\end{array}$ & $\begin{array}{l}\text { Abutment } \\
\text { scour } \\
\text { depth } \\
\text { (feet) }\end{array}$ & $\begin{array}{l}\text { Pier } \\
\text { scour } \\
\text { depth } \\
\text { (feet) }\end{array}$ & $\begin{array}{l}\text { Depth of } \\
\text { total scour } \\
\text { (feet) }\end{array}$ & $\begin{array}{c}\text { Elevation of } \\
\text { scour }^{2} \\
\text { (feet) }\end{array}$ & $\begin{array}{c}\text { Remaining } \\
\text { footing/pile } \\
\text { depth } \\
\text { (feet) }\end{array}$ \\
\hline \multicolumn{12}{|c|}{500 -yr. discharge is 1,730 cubic-feet per second } \\
\hline Left abutment & 0.0 & -- & 96.2 & -- & 90.9 & 2.8 & 11.4 & -- & 14.2 & 76.7 & -- \\
\hline Right abutment & 22.8 & -- & 96.2 & -- & 90.3 & 2.8 & 16.5 & -- & 19.3 & 71.0 & -- \\
\hline
\end{tabular}

${ }^{1}$. Measured along the face of the most constricting side of the bridge.

2. Arbitrary datum for this study. 


\section{SELECTED REFERENCES}

Arcement, G.J., Jr., and Schneider, V.R., 1989, Guide for selecting Manning's roughness coefficients for natural channels and flood plains: U.S. Geological Survey Water-Supply Paper 2339, 38 p.

Barnes, H.H., Jr., 1967, Roughness characteristics of natural channels: U.S. Geological Survey Water-Supply Paper 1849, 213 p.

Benson, M.A., 1962, Factors Influencing the Occurrence of Floods in a Humid Region of Diverse Terrain, U.S. Geological Survey Water-supply Paper 1580 B, 64 p.

Brown, S.A. and Clyde, E.S., 1989, Design of riprap revetment: Federal Highway Administration Hydraulic Engineering Circular No. 11, Publication FHWA-IP-89-016, 156 p.

Federal Highway Administration, 1983, Runoff estimates for small watersheds and development of sound design: Federal Highway Administration Report FHWA-RD-77-158

Froehlich, D.C., 1989, Local scour at bridge abutments in Ports, M.A., ed., Hydraulic Engineering--Proceedings of the 1989 National Conference on Hydraulic Engineering: New York, American Society of Civil Engineers, p. 13-18.

Hayes, D.C.,1993, Site selection and collection of bridge-scour data in Delaware, Maryland, and Virginia: U.S. Geological Survey Water-Resources Investigation Report 93-4017, 23 p.

Johnson, C.G. and Tasker, G.D.,1974, Progress report on flood magnitude and frequency of Vermont streams: U.S. Geological Survey Open-File Report 74-130, 37 p.

Lagasse, P.F., Schall, J.D., Johnson, F., Richardson, E.V., Chang, F., 1995, Stream Stability at Highway Structures: Federal Highway Administration Hydraulic Engineering Circular No. 20, Publication FHWA-IP-90-014, 144 p.

Laursen, E.M., 1960, Scour at bridge crossings: Journal of the Hydraulics Division, American Society of Civil Engineers, v. 86, no. HY2, p. 39-53.

Potter, W. D., 1957a, Peak rates of runoff in the Adirondack, White Mountains, and Maine woods area, Bureau of Public Roads

Potter, W. D., 1957b, Peak rates of runoff in the New England Hill and Lowland area, Bureau of Public Roads

Richardson, E.V. and Davis, S.R., 1995, Evaluating scour at bridges: Federal Highway Administration Hydraulic Engineering Circular No. 18, Publication FHWA-IP-90-017, 204 p.

Richardson, E.V., Simons, D.B., and Julien, P.Y., 1990, Highways in the river environment: Federal Highway Administration Publication FHWA-HI-90-016.

Ritter, D.F., 1984, Process Geomorphology: W.C. Brown Co., Debuque, Iowa, 603 p.

Shearman, J.O., 1990, User's manual for WSPRO--a computer model for water surface profile computations: Federal Highway Administration Publication FHWA-IP-89-027, 187 p.

Shearman, J.O., Kirby, W.H., Schneider, V.R., and Flippo, H.N., 1986, Bridge waterways analysis model; research report: Federal Highway Administration Publication FHWA-RD-86-108, 112 .

Talbot, A.N., 1887, The determination of water-way for bridges and culverts.

U.S. Department of Transportation, 1993, Stream stability and scour at highway bridges, Participant Workbook: Federal Highway Administration Publication FHWA HI-91-011.

U.S. Geological Survey, 1986, Crystal Lake, Vermont 7.5 Minute Series quadrangle map, Provisional edition: U.S. Geological Survey Topographic Maps, aerial photography, 1980, contour interval, 6 meters, Scale 1:24,000. 


\section{APPENDIX A: \\ WSPRO INPUT FILE}




\section{WSPRO INPUT FILE}

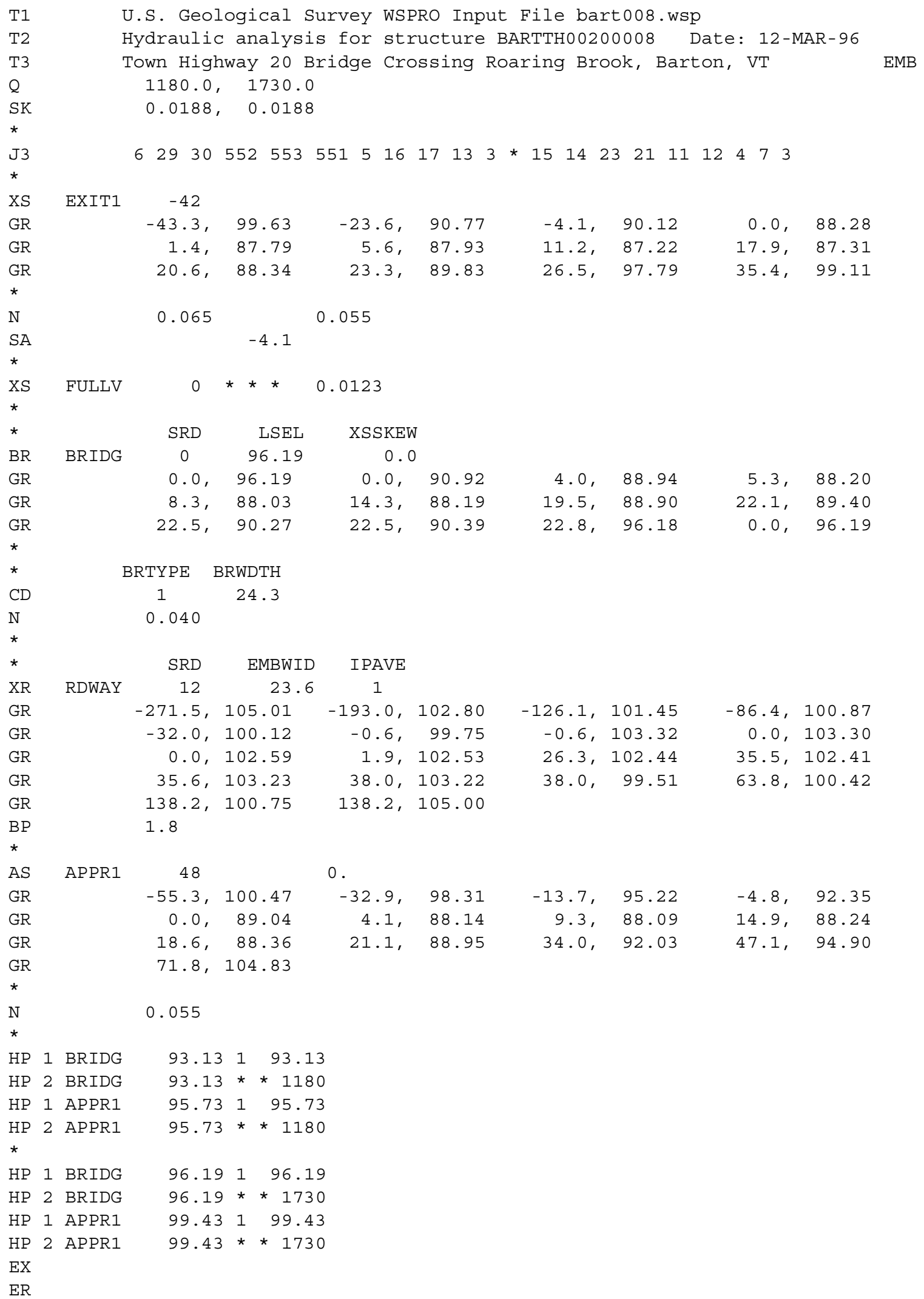




\section{APPENDIX B: \\ WSPRO OUTPUT FILE}




\section{WSPRO OUTPUT FILE}

\begin{tabular}{|c|c|c|c|c|c|c|c|c|c|c|c|}
\hline & CROSS-SEC & ECTION & J PROPER & TIES: & ISEQ & $=3 i$ & SECID & $D=B R I D G ;$ & SRD & $=$ & 0 . \\
\hline & WSEL & SA\# & AREA & & K & TOPW & WETP & $\mathrm{ALPH}$ & LEW & REW & QCR \\
\hline & & 1 & 100 & & 8466 & 23 & 29 & & & & 1185 \\
\hline & 93.13 & & 100 & & 8466 & 23 & 29 & 1.00 & 0 & 23 & 1185 \\
\hline & VELOCITY & Y DIST & RRIBUTIO & & ISEQ = & $3 ;$ & SECID = & BRIDG ; & $\mathrm{SRD}=$ & & 0 . \\
\hline & WSEL & & LEW & REW & $A R$ & EA & $\mathrm{K}$ & $Q$ & VEL & & \\
\hline & 93.13 & & 0.0 & 22.6 & 99 & .6 & 8466 . & 1180. & 11.85 & & \\
\hline $\mathrm{X}$ & STA. & 0 . & & 2.9 & & 4.4 & & 5.5 & 6.4 & & 7.3 \\
\hline & $A(I)$ & & 8.7 & & 5.9 & & 5.2 & 4.6 & & 4.4 & \\
\hline & $V(I)$ & & 6.81 & & 10.03 & & 11.38 & 12.82 & & 13.37 & \\
\hline $\mathrm{X}$ & STA. & 7. & & 8.1 & & 9.0 & & 9.8 & 10.6 & & 11.4 \\
\hline & $A(I)$ & & 4.2 & & 4.2 & & 4.2 & 4.1 & & 4.1 & \\
\hline & $V(I)$ & & 13.90 & & 14.11 & & 14.06 & 14.28 & & 14.34 & \\
\hline $\mathrm{X}$ & STA. & 11. & & 12.3 & & 13.1 & & 13.9 & 14.8 & & 15.7 \\
\hline & $A(I)$ & & 4.2 & & 4.1 & & 4.2 & 4.3 & & 4.3 & \\
\hline & $V(I)$ & & 14.18 & & 14.25 & & 14.14 & 13.79 & & 13.61 & \\
\hline $\mathrm{X}$ & STA. & 15. & & 16.7 & & 17.7 & & 18.9 & 20.2 & & 22.6 \\
\hline & $A(I)$ & & 4.6 & & 4.7 & & 5.1 & 5.5 & & 9.0 & \\
\hline & $V(I)$ & & 12.78 & & 12.58 & & 11.53 & 10.77 & & 6.56 & \\
\hline & CROSS-SEC & CTION & PROPER & TIES : & ISEQ & $=5 i$ & SECID & $D=A P P R 1 ;$ & SRD & $=$ & 48 \\
\hline & WSEL SA & SA\# & AREA & & $\mathrm{K}$ & TOPW & WETP & $\mathrm{ALPH}$ & LEW & REW & $\mathrm{QCR}$ \\
\hline & & 1 & 297 & & 21360 & 66 & 69 & & & & 3571 \\
\hline & 95.73 & & 297 & & 21360 & 66 & 69 & 1.00 & -16 & 49 & 3571 \\
\hline & VELOCITY & DIST & RIBUTIOI & & ISEQ = & $5 ;$ & SECID $=$ & APPR1; & $\mathrm{SRD}=$ & & 48 . \\
\hline & WSEL & & LEW & REW & $A R$ & EA & K & Q & VEL & & \\
\hline & 95.73 & & 16.9 & 49.2 & 296 & & 21360 . & 1180. & 3.98 & & \\
\hline $\mathrm{X}$ & STA. & -16 & & -2.5 & & 0.5 & & 2.6 & 4.3 & & 6.0 \\
\hline & $A(I)$ & & 27.7 & & 18.3 & & 14.5 & 13.0 & & 12.9 & \\
\hline & $V(I)$ & & 2.13 & & 3.23 & & 4.06 & 4.54 & & 4.59 & \\
\hline $\mathrm{X}$ & STA. & 6. & & 7.6 & & 9.1 & & 10.7 & 12.2 & & 13.8 \\
\hline & $A(I)$ & & 11.9 & & 11.7 & & 11.8 & 11.6 & & 11.6 & \\
\hline & $V(I)$ & & 4.94 & & 5.03 & & 4.99 & 5.08 & & 5.11 & \\
\hline $\mathrm{x}$ & STA. & $13 . \varepsilon$ & & 15.3 & & 16.9 & & 18.5 & 20.2 & & 22.1 \\
\hline & $A(I)$ & & 11.5 & & 11.8 & & 12.1 & 12.3 & & 12.8 & \\
\hline & $V(I)$ & & 5.14 & & 5.01 & & 4.89 & 4.78 & & 4.61 & \\
\hline $\mathrm{X}$ & STA. & 22. & & 24.3 & & 26.9 & & 30.2 & 34.8 & & 49.2 \\
\hline & $A(I)$ & & 14.0 & & 14.6 & & 16.4 & 18.7 & & 27.7 & \\
\hline & $V(I)$ & & 4.21 & & 4.03 & & 3.61 & 3.16 & & 2.13 & \\
\hline
\end{tabular}




\section{WSPRO OUTPUT FILE (continued)}

\begin{tabular}{|c|c|c|c|c|c|c|c|c|c|c|c|}
\hline & CROSS - SEC & ECTION & PROPERT & RTIES : & ISEQ & $=$ & SECID & $D=B R I D G ;$ & SRD & $=$ & 0 . \\
\hline & WSEL SA & SA\# & AREA & & K & TOPW & WETP & $\mathrm{ALPH}$ & LEW & REW & QCR \\
\hline & & 1 & 169 & & 2872 & & 58 & & & & 0 \\
\hline & 96.19 & & 169 & & 2872 & & 58 & 1.00 & 0 & 23 & 0 \\
\hline & VELOCITY & Y DISTF & RIBUTION & $\mathrm{N}:$ & $\mathrm{SEQ}=$ & $3 ;$ & SECID $=$ & BRIDG ; & $\mathrm{SRD}=$ & & 0 . \\
\hline & WSEI & EL & LEW & REW & ARI & EA & K & $Q$ & VEL & & \\
\hline & 96.19 & & 0.0 & 22.8 & 169 & .0 & 12872 . & 1730. & 10.24 & & \\
\hline $\mathrm{X}$ & STA. & 0.0 & & 2.4 & & 3.8 & & 5.0 & 6.0 & & 6.9 \\
\hline & $A(I)$ & & 14.4 & & 9.5 & & 8.8 & 7.9 & & 7.4 & \\
\hline & $V(I)$ & & 6.01 & & 9.06 & & 9.78 & 10.89 & & 11.62 & \\
\hline $\mathrm{x}$ & STA. & 6.9 & & 7.9 & & 8.8 & & 9.6 & 10.5 & & 11.4 \\
\hline & $A(I)$ & & 7.3 & & 7.3 & & 7.2 & 7.1 & & 7.1 & \\
\hline & $V(I)$ & & 11.80 & & 11.79 & & 11.96 & 12.14 & & 12.17 & \\
\hline $\mathrm{X}$ & STA. & 11.4 & & 12.3 & & 13.2 & & 14.1 & 15.0 & & 16.0 \\
\hline & $A(I)$ & & 7.2 & & 7.2 & & 7.2 & 7.3 & & 7.5 & \\
\hline & $V(I)$ & & 12.04 & & 12.08 & & 11.97 & 11.90 & & 11.48 & \\
\hline $\mathrm{X}$ & STA. & 16.0 & & 17.0 & & 18.0 & & 19.2 & 20.5 & & 22.8 \\
\hline & $A(I)$ & & 7.7 & & 8.0 & & 8.5 & 9.5 & & 14.6 & \\
\hline & $V(I)$ & & 11.25 & & 10.80 & & 10.13 & 9.13 & & 5.92 & \\
\hline & CROSS-SEC & ECTION & PROPERT & TIES: & ISEQ & $=5$ & SECID & $D=A P P R 1 ;$ & SRD & $D=$ & 48 \\
\hline & WSEL SA & SA\# & AREA & & $\mathrm{K}$ & TOPW & WETP & $\mathrm{ALPH}$ & LEW & REW & QCR \\
\hline & & 1 & 603 & & 51977 & 103 & 106 & & & & 8290 \\
\hline & 99.43 & & 603 & & $\$ 1977$ & 103 & 106 & 1.00 & -44 & 58 & 8290 \\
\hline & VELOCITY & Y DISTR & RIBUTIOI & $\mathrm{N}:$ & $\mathrm{SEQ}=$ & $5 ;$ & $\mathrm{SECID}=$ & APPR1; & $\mathrm{SRD}=$ & & 48 \\
\hline & WSEI & & LEW & REW & ARI & EA & $\mathrm{K}$ & Q & VEL & & \\
\hline & 99.43 & & 44.5 & 58.4 & 603 & & 51977. & 1730. & 2.87 & & \\
\hline $\mathrm{X}$ & STA. & -44.5 & & -11.8 & & -4.6 & & -0.5 & 2.3 & & 4.7 \\
\hline & $A(I)$ & & 66.4 & & 43.2 & & 35.0 & 30.2 & & 26.7 & \\
\hline & $V(I)$ & & 1.30 & & 2.00 & & 2.47 & 2.87 & & 3.24 & \\
\hline $\mathrm{x}$ & STA. & 4.7 & & 7.0 & & 9.1 & & 11.2 & 13.3 & & 15.4 \\
\hline & $A(I)$ & & 25.4 & & 24.5 & & 23.7 & 23.3 & & 23.2 & \\
\hline & $V(I)$ & & 3.41 & & 3.53 & & 3.65 & 3.71 & & 3.73 & \\
\hline $\mathrm{X}$ & STA. & 15.4 & & 17.4 & & 19.4 & & 21.6 & 24.0 & & 26.6 \\
\hline & $A(I)$ & & 22.6 & & 22.4 & & 23.3 & 23.7 & & 25.0 & \\
\hline & $V(I)$ & & 3.83 & & 3.86 & & 3.71 & 3.65 & & 3.46 & \\
\hline $\mathrm{X}$ & STA. & 26.6 & & 29.5 & & 32.9 & & 37.1 & 42.6 & & 58.4 \\
\hline & $A(I)$ & & 25.3 & & 27.6 & & 29.8 & 33.9 & & 48.2 & \\
\hline & $V(I)$ & & 3.42 & & 3.13 & & 2.90 & 2.55 & & 1.79 & \\
\hline
\end{tabular}




\section{WSPRO OUTPUT FILE (continued)}

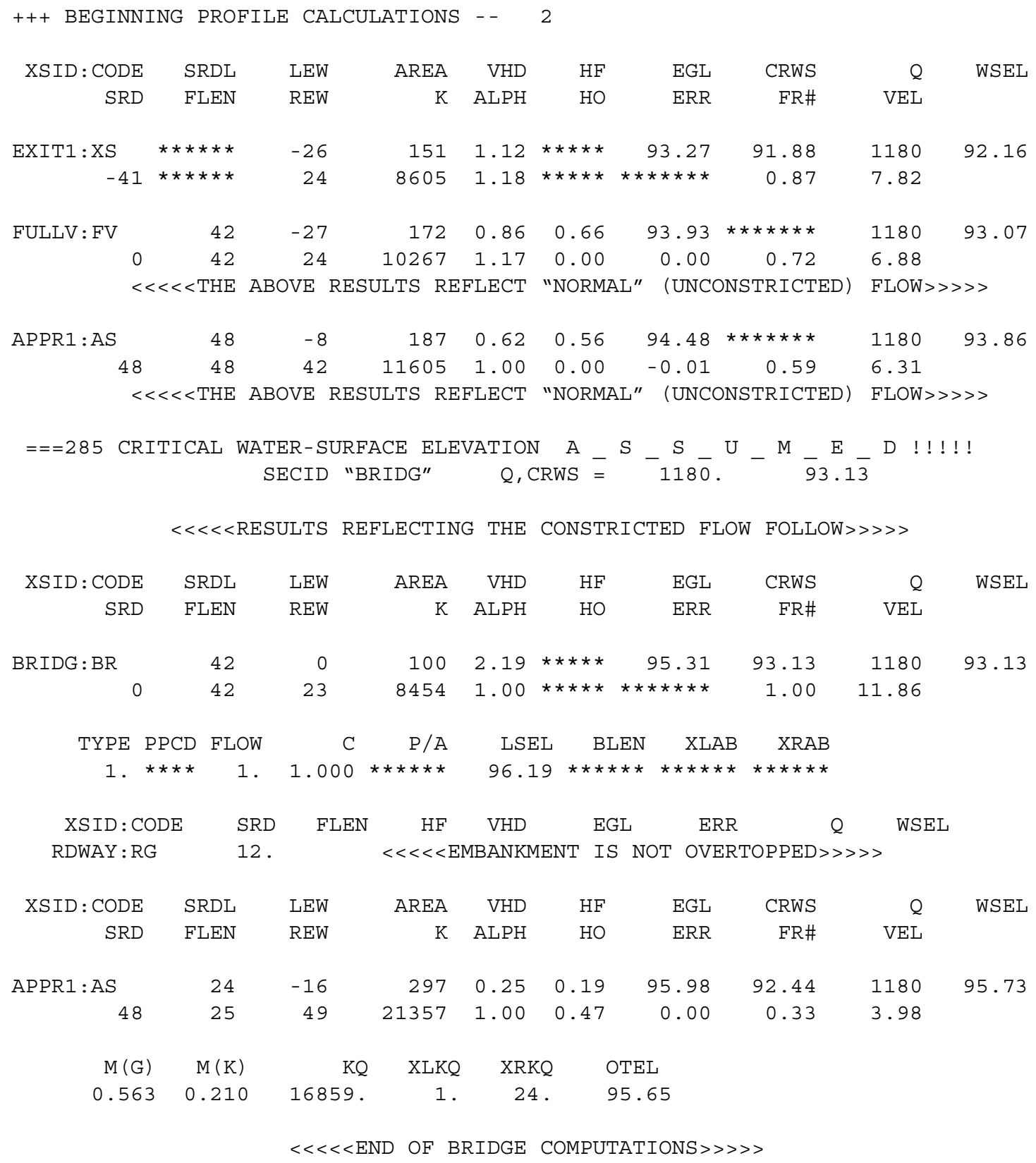

\begin{tabular}{|c|c|c|c|c|c|c|c|c|}
\hline XSID : CODE & SRD & LEW & REW & $\mathrm{Q}$ & $\mathrm{K}$ & AREA & VEL & WSEL \\
\hline EXIT1:XS & -42 & -27 & 24 . & 1180. & 8605 . & 151. & 7.82 & 92.16 \\
\hline FULLV : FV & 0 . & -28 & 24 . & 1180. & 10267 . & 172 . & 6.88 & 93.07 \\
\hline BRIDG : BR & 0 . & 0. & 23 . & 1180. & 8454 . & 100 & 11.86 & 93.13 \\
\hline RDWAY : RG & \multicolumn{3}{|c|}{ 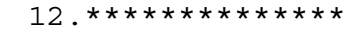 } & \multicolumn{3}{|c|}{ 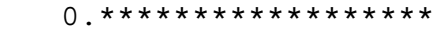 } & \multicolumn{2}{|c|}{$1.00 * * * * * * * *$} \\
\hline APPR1:AS & 48. & -17 & 49. & 1180 & 21357 . & 297. & 3.98 & 95.73 \\
\hline XSID : CODE & XLKQ & XRKQ & & & & & & \\
\hline APPR $1:$ AS & 1 . & 24. & 16859 & & & & & \\
\hline
\end{tabular}




\section{WSPRO OUTPUT FILE (continued)}

SECOND USER DEFINED TABLE.

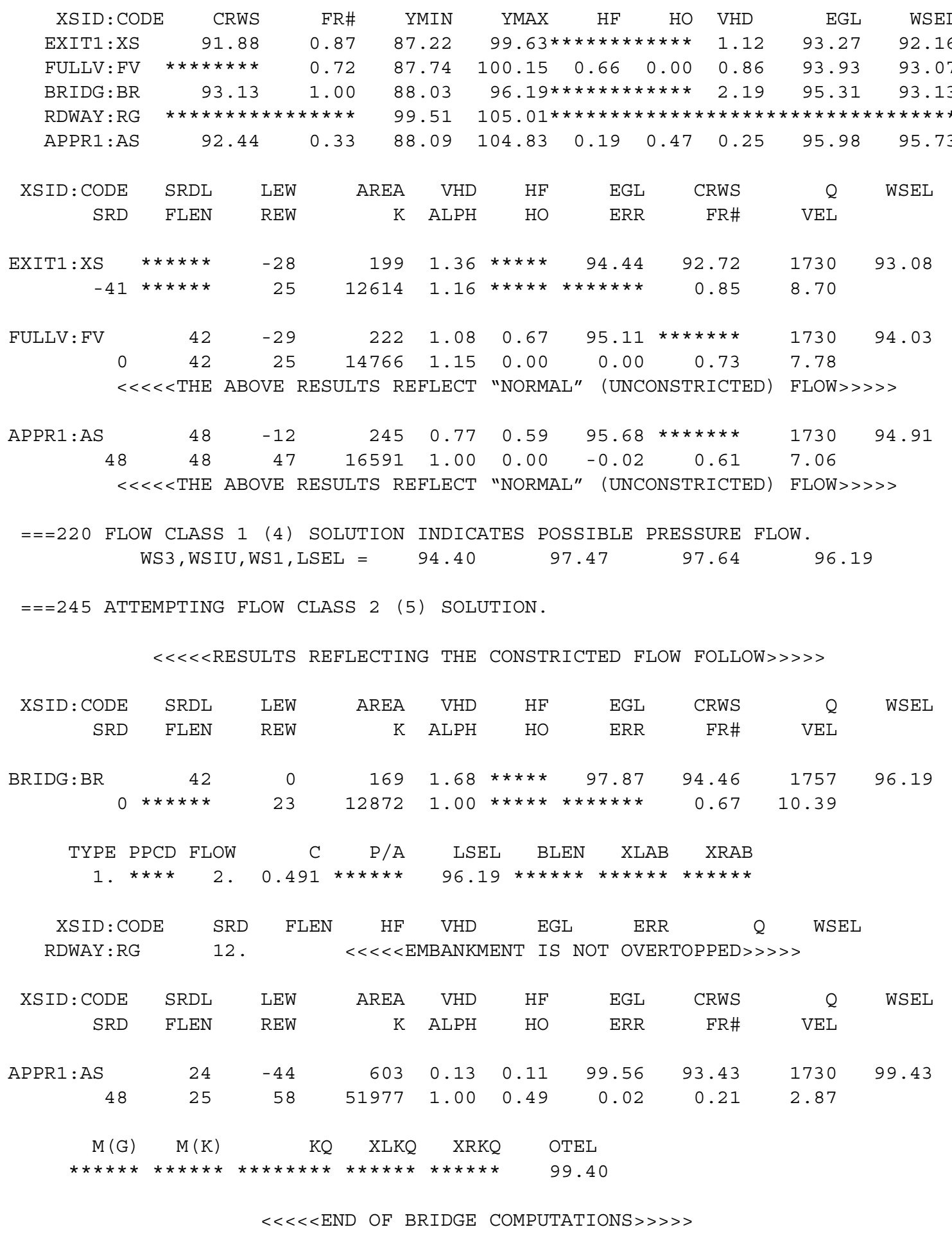

FIRST USER DEFINED TABLE.

\begin{tabular}{|c|c|c|c|c|c|c|c|c|}
\hline XSID:CODE & SRD & LEW & REW & $Q$ & $\mathrm{~K}$ & AREA & VEL & WSEL \\
\hline EXIT1:XS & -42 & -29 & 25 . & 1730. & 12614 . & 199. & 8.70 & 93.08 \\
\hline FULLV : FV & 0 . & -30 & 25 . & 1730. & 14766 . & 222 . & 7.78 & 94.03 \\
\hline BRIDG : BR & 0 . & 0. & 23. & 1757. & 12872 . & 169. & 10.39 & 96.19 \\
\hline RDWAY : RG & \multicolumn{3}{|c|}{$12 . * * * * * * * * * * \star * \star * *$} & \multicolumn{3}{|c|}{$0 . * * * * * * * * * * * * \star * * * * * *$} & \multicolumn{2}{|c|}{$1.00 * * * * * * * *$} \\
\hline APPR $1:$ AS & 48 . & -45 & 58. & 1730. & 51977. & 603. & 2.87 & 99.43 \\
\hline
\end{tabular}




\section{WSPRO OUTPUT FILE (continued)}

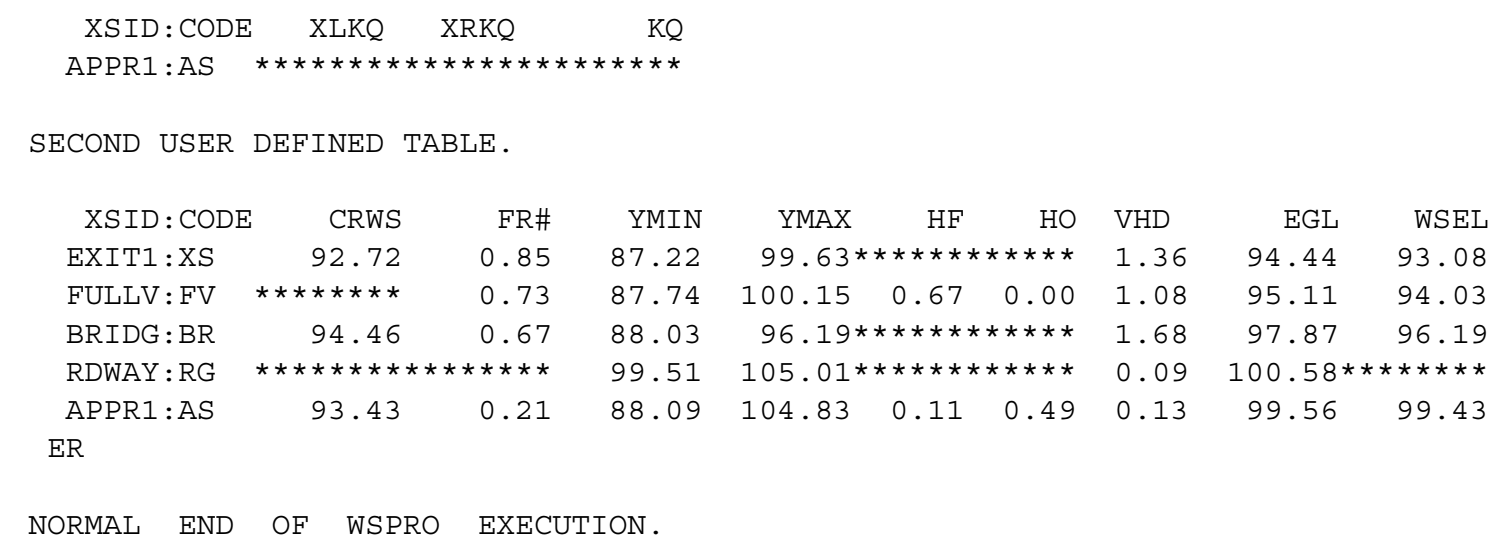




\section{APPENDIX C:}

\section{BED-MATERIAL PARTICAL-SIZE DISTRIBUTION}




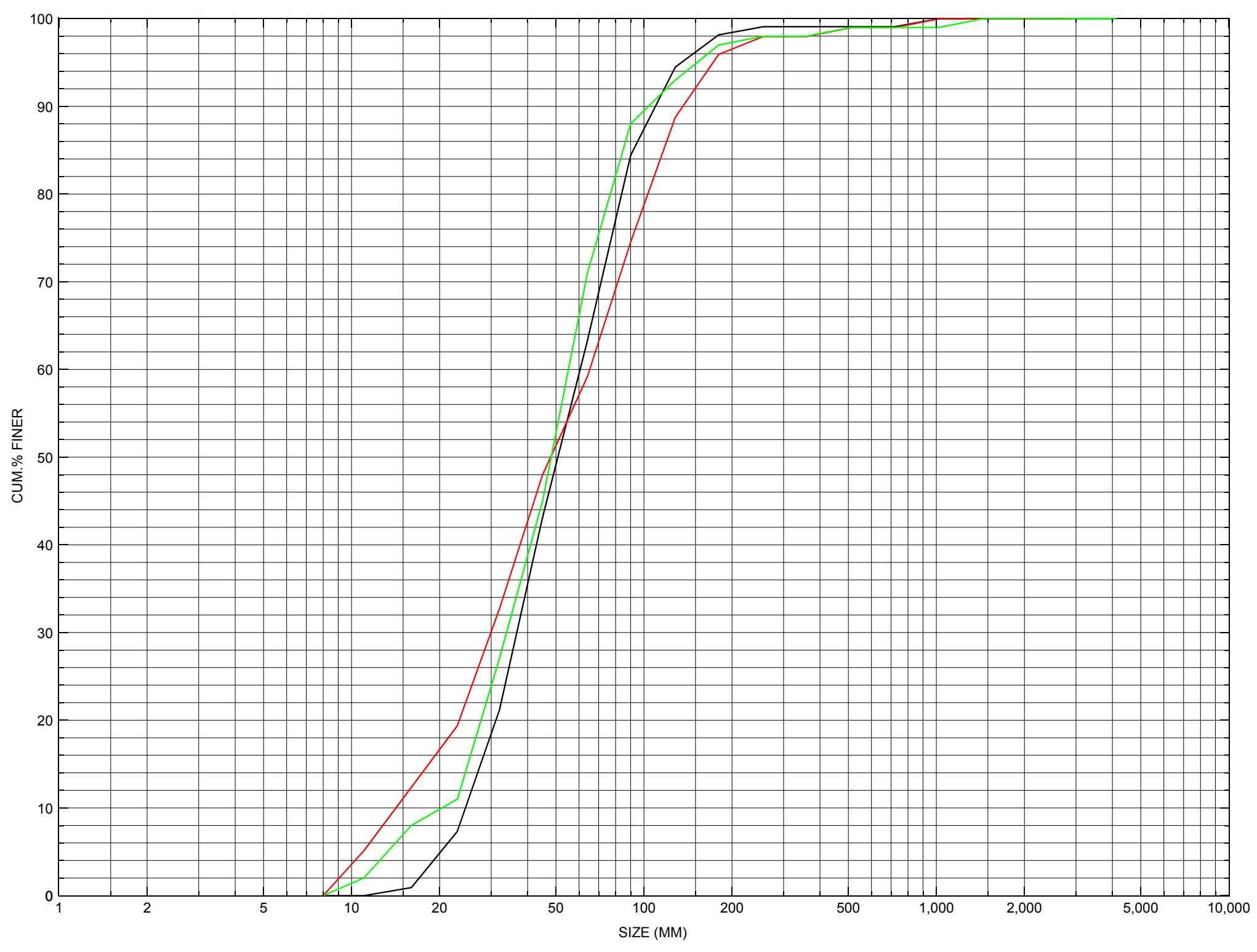

Appendix C. Bed material particle-size distributions for three pebble count transects at the approach cross-section for structure BARTTH00020008, in Barton, Vermont. 


\section{APPENDIX D: \\ HISTORICAL DATA FORM}




\section{Structure Number BARTTH00020008}

\section{General Location Descriptive}

Data collected by (First Initial, Full last name) $\mathbf{M}$. WEBER

Date $(M M / D D / Y Y) \_\mathbf{0 8} / \underline{\mathbf{0 4}} / \underline{\mathbf{9 4}}$

Highway District Number (I - 2; nn) 09

Town (FIPS place code; I - 4; nnnnn) $\mathbf{0 3 5 5 0}$

Waterway (I - 6) Roaring Brook

Route Number $\underline{\text { TH002 }}$

Topographic Map Crystal.Lake

Latitude (I - 16; nnnn.n) $\mathbf{4 4 4 4 3}$
County (FIPS county code; I - 3; nnn)

Mile marker (I - 11; nnn.nnn) $\mathbf{0 0 0 0 0 0}$

Road Name ( -7$)$ : Roaring Brook Road

Vicinity (I - 9) 0.05 MI TO JCT W C3 TH43

Hydrologic Unit Code: $\mathbf{0 1 1 1 0 0 0 0}$

Longitude (i - 17; nnnnn.n) $\mathbf{7 2 1 2 8}$

\section{Select Federal Inventory Codes}

FHWA Structure Number (I - 8) $\mathbf{1 0 1 0 0 2 0 0 0 8 1 0 0 2}$

Maintenance responsibility $(I-21 ; n n) \quad \mathbf{0 3} \quad$ Maximum span length $(I-48 ; n n n n) \underline{\mathbf{0 0 2 6}}$

Year built (I - 27; YYYY) 1928

Structure length (I - 49; nnnnnn) $\underline{\mathbf{0 0 0 0 3 0}}$

Average daily traffic, ADT (I - 29; nnnnnn) 000730 Deck Width (I- 52; nn.n) 236

Year of ADT (I - 30; YY) $\underline{\mathbf{9 1}}$

Channel \& Protection $(I-61 ; n) \underline{6}$

Opening skew to Roadway $(I-34 ; n n) \quad \mathbf{0 0}$

Waterway adequacy $(I-71 ; n)$

Operational status $(I-41 ; X)$ A

Underwater Inspection Frequency $(I-92 B ; X Y Y) \_\mathbf{N}$

Structure type (I - 43; nnn) 104

Year Reconstructed (I - 106) $\mathbf{0 0 0 0}$

Approach span structure type (I - 44; nnn) $\mathbf{0 0 0}$ Clear span (nnn.n ft) _ _

Number of spans (I - 45; nnn) $\mathbf{0 0 1}$

Vertical clearance from streambed (nnn.n ft) $\underline{\mathbf{0 0 7 . 0}}$

Number of approach spans (I - 46; nnnn) $\mathbf{0 0 0 0}$ Waterway of full opening $\left(n n n . n \mathrm{ft}^{2}\right)$

Comments:

Structural inspection report of 7/18/92 indicates settlement on the left abutment. The fascia T-beams have heavy section loss and exposed rebar spalling. Extensive spalling at the bottom left abutment with large aggregate exposed. Moderate channel turn upstream then sharp turn downstream with bank erosion. The bridge is in fair to poor condition. Photos with bridge record show large scour holes at unspecified wing walls above the ambient water surface. Also the photos show rail damage. 


\section{Bridge Hydrologic Data}

Is there hydrologic data available? $\underline{\mathbf{Y}}$ if No, type ctrl-n $h \quad$ VTAOT Drainage area $\left(\mathrm{mi}^{2}\right): \underline{\mathbf{9 . 9 2}}$

Terrain character:

Stream character \& type: -

Streambed material: Stones and gravel and random boulders

Discharge Data (cfs): $\quad \mathrm{Q}_{2.33}-$

$$
\mathrm{Q}_{50}-
$$

Record flood date $(M M / D D / Y Y):-$

$\begin{array}{ll}Q_{10}- & Q_{25}- \\ Q_{100 \_-} & Q_{500-}-\end{array}$

Water surface elevation $(f t):-$

Estimated Discharge (cfs): Velocity at $\mathrm{Q}-$ $(\mathrm{ft} / \mathrm{s}):$

Ice conditions (Heavy, Moderate, Light) : - _ Debris (Heavy, Moderate, Light): HEAVY

The stage increases to maximum highwater elevation (Rapidly, Not rapidly):

The stream response is (Flashy, Not flashy):

Describe any significant site conditions upstream or downstream that may influence the stream's stage: -

Watershed storage area (in percent): - _ \%

The watershed storage area is: - _ (1-mainly at the headwaters; 2- uniformly distributed; 3-immediatly upstream oi the site)

Water Surface Elevation Estimates for Existing Structure:

\begin{tabular}{|l|l|l|l|l|l|}
\hline Peak discharge frequency & $Q_{2.33}$ & $Q_{10}$ & $Q_{25}$ & $Q_{50}$ & $Q_{100}$ \\
Water surface elevation (ft)) & - & - & - & - & - \\
Velocity (ft/sec) & - & - & - & - & - \\
\hline
\end{tabular}

Long term stream bed changes: -

Is the roadway overtopped below the $\mathrm{Q}_{100}$ ? (Yes, No, Unknown): $\mathbf{U} \quad$ Frequency: Relief Elevation $(f t)$ : Discharge over roadway at $\mathrm{Q}_{100}\left(\mathrm{ft}^{3} / \mathrm{sec}\right)$ :

Are there other structures nearby? (Yes, No, Unknown): $\mathbf{U}$ Upstream distance (miles): Town: If No or Unknown, type ctrl-n os Highway No. : Structure No. : Year Built:

Clear span (ft): Clear Height (ft): Full Waterway $\left(f^{2}\right)$ : 
Downstream distance (miles): Town: Year Built:

Highway No. : Structure No. : Structure Type:

Clear span (ft): Clear Height $(f t)$ : Full Waterway $\left(f^{2}\right)$ : -

Comments:

\section{USGS Watershed Data}

Watershed Hydrographic Data Drainage area $(D A) \quad 9.89 \quad \mathrm{mi}^{2}$

Watershed storage (ST) 4.8 Lake and pond area

0.47 $\mathrm{mi}^{2}$

Bridge site elevation 1147 $\mathrm{ft}$ $\%$

Main channel length 6.01 $\mathrm{mi}$ $10 \%$ channel length elevation 1220 $\mathrm{ft} \quad 85 \%$ channel length elevation $\mathrm{ft}$

Main channel slope $(S)$
(S) 117.9 $\mathrm{ft} / \mathrm{mi}$

Watershed Precipitation Data

Average site precipitation in Average headwater precipitation in

Maximum 2yr-24hr precipitation event $(124,2)$ in

Average seasonal snowfall (Sn) $\mathrm{ft}$ 


\section{Bridge Plan Data}

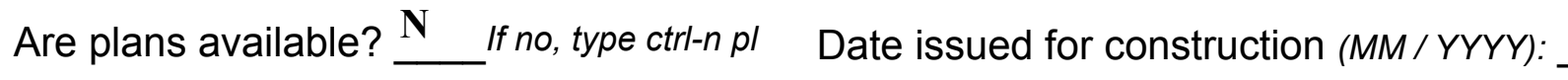

Project Number -

Minimum channel bed elevation:

Low superstructure elevation: USLAB DSLAB USRAB DSRAB Benchmark location description:

-

Reference Point (MSL, Arbitrary, Other):

Datum (NAD27, NAD83, Other):

Foundation Type: 4

If 1: Footing Thickness

If 2: Pile Type: (1-Wood; 2-St

(1-

(1-Spreadfooting; 2-Pile; 3- Gravity; 4-Unknown)

Footing bottom elevation:

If 3 : Footing bottom elevation:

Is boring information available?
Foundation Material Type: $\mathbf{3}$

Foundation Material Type: 3

Briefly describe material at foundation bottom elevation or around piles:

Comments:

NO PLANS 


\section{Cross-sectional Data}

Is cross-sectional data available? $\mathbf{N}$ If no, type ctrl-n xs

Source (FEMA, VTAOT, Other)? -

Comments: NO CROSS SECTION INFORMATION AVAILABLE.

\begin{tabular}{|l|l|l|l|l|l|l|l|l|l|l|l|}
\hline Station & - & - & - & - & - & - & - & - & - & - & - \\
\hline Feature & - & - & - & - & - & - & - & - & - & - & - \\
\hline $\begin{array}{l}\text { Low cord } \\
\text { elevation }\end{array}$ & - & - & - & - & - & - & - & - & - & - & - \\
\hline $\begin{array}{l}\text { Bed } \\
\text { elevation }\end{array}$ & - & - & - & - & - & - & - & - & - & - & - \\
\hline $\begin{array}{l}\text { Low cord to } \\
\text { bed length }\end{array}$ & - & - & - & - & - & - & - & - & - & - & - \\
\hline Station & - & - & - & - & - & - & - & - & - & - & - \\
\hline Feature & - & - & - & - & - & - & - & - & - & - & - \\
\hline $\begin{array}{l}\text { Low cord } \\
\text { elevation }\end{array}$ & - & - & - & - & - & - & - & - & - & - & - \\
\hline $\begin{array}{l}\text { Bed } \\
\text { elevation }\end{array}$ & - & - & - & - & - & - & - & - & - & - & - \\
\hline $\begin{array}{l}\text { Low cord to } \\
\text { bed length }\end{array}$ & - & - & - & - & - & - & - & - & - & - & - \\
\hline
\end{tabular}

Source (FEMA, VTAOT, Other)?

Comments: -

\begin{tabular}{|l|l|l|l|l|l|l|l|l|l|l|l|}
\hline Station & - & - & - & - & - & - & - & - & - & - & - \\
\hline Feature & - & - & - & - & - & - & - & - & - & - & - \\
\hline $\begin{array}{l}\text { Low cord } \\
\text { elevation }\end{array}$ & - & - & - & - & - & - & - & - & - & - & - \\
\hline $\begin{array}{l}\text { Bed } \\
\text { elevation }\end{array}$ & - & - & - & - & - & - & - & - & - & - & - \\
\hline $\begin{array}{l}\text { Low cord to } \\
\text { bed length }\end{array}$ & - & - & - & - & - & - & - & - & - & - & - \\
\hline Station & - & - & - & - & - & - & - & - & - & - & - \\
\hline Feature & - & - & - & - & - & - & - & - & - & - & - \\
\hline $\begin{array}{l}\text { Low cord } \\
\text { elevation }\end{array}$ & - & - & - & - & - & - & - & - & - & - & - \\
\hline $\begin{array}{l}\text { Bed } \\
\text { elevation }\end{array}$ & - & - & - & - & - & - & - & - & - & - & - \\
\hline $\begin{array}{l}\text { Low cord to } \\
\text { bed length }\end{array}$ & - & - & - & - & - & - & - & - & - & - & - \\
\hline
\end{tabular}




\section{APPENDIX E: \\ LEVEL I DATA FORM}


U. S. Geological Survey

Bridge Field Data Collection and Processing Form

Qa/Qc Check by: EMB Date: 2/9/95

\section{A. General Location Descriptive}

1. Data collected by (First Initial, Full last name) M. IVANOFF

2. Highway District Number 09

County Orleans (019)

Waterway (I - 6) Roaring Brook

Route Number $\mathbf{T H 0 0 2}$
Date $(M M / D D / Y Y) \underline{10} / \underline{18} / \underline{1994}$

3. Descriptive comments:

Mile marker $\mathbf{0}$

Located 0.005 miles from the junction of TH 2 and TH 43 and 1.5 miles west of the intersection of TH 2 and VT 16.

\section{B. Bridge Deck Observations}
4. Surface cover... LBUS 6
RBUS 6
LBDS 5
RBDS 6
Overall 6

(2b us,ds,lb,rb: 1- Urban; 2- Suburban; 3- Row crops; 4- Pasture; 5- Shrub- and brushland; 6- Forest; 7- Wetland)
5. Ambient water surface... US $\underline{2}$
UB 1
DS 1
(1- pool; 2- riffle)

6. Bridge structure type 1 (1- single span; 2- multiple span; 3- single arch; 4- multiple arch; 5-cylindrical culvert; 6- box culvert; or 7- other)
7. Bridge length $\mathbf{3 0}$
(feet)
Span length 26
(feet)
Bridge width $\underline{\mathbf{2 3 . 6}}$ (feet)

\section{Road approach to bridge:}
8. LB 0
RB 2
( 0 even, 1- lower, 2- higher)
9. LB 1 RB 1
(1-Paved, 2- Not paved)

10. Embankment slope (run / rise in feet / foot)

$$
\text { US left }
$$

0.0:1

US right

0.0:1

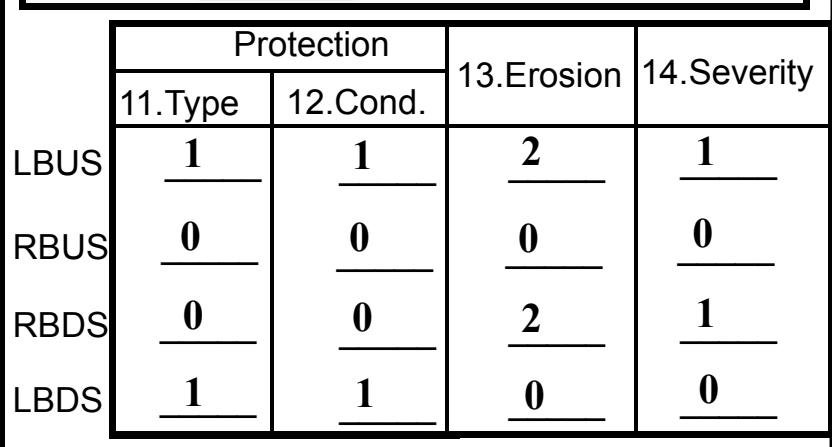

Bank protection types: 0- none; 1- $<12$ inches;

$$
\text { 2- < } 36 \text { inches; 3- < } 48 \text { inches; }
$$

4- < 60 inches; 5- wall / artificial levee

Bank protection conditions: 1- good; 2- slumped;

3- eroded; 4- failed

Erosion: 0 - none; 1- channel erosion; 2-

road wash; 3- both; 4- other

Erosion Severity: 0 - none; 1- slight; 2- moderate; 3- severe

\section{Channel approach to bridge (BF):}

15. Angle of approach: 15

16. Bridge skew: 15

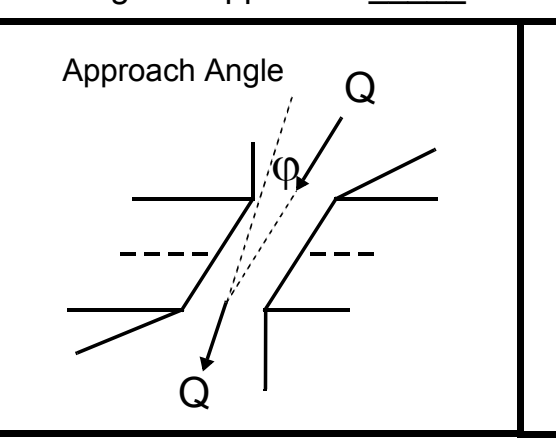

17. Channel impact zone 1:

Where? RB (LB, RB)

Exist? $\mathbf{Y}(Y$ or $N)$ Bridge Skew Angle

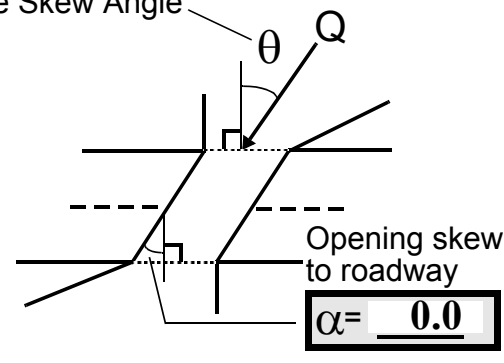

Range? 30 feet DS

Severity $\mathbf{0}$

Channel impact zone 2:

Where? RB (LB, RB)

Exist? $\underline{\mathbf{Y}}(\mathrm{Y}$ or $N)$

Range? $\underline{\mathbf{0}}$ feet $\underline{\mathbf{U S}}$

Severity 1

Impact Severity: 0- none to very slight; 1- Slight; 2- Moderate; 3- Severe 
18. Level II Bridge Type: 1b

1a- Vertical abutments with wingwalls

$1 \mathrm{~b}$ - Vertical abutments without wingwalls

2- Vertical abutments and wingwalls, sloping embankment

Wingwalls perpendicular to abut. face

3- Spill through abutments

4- Sloping embankment, vertical wingwalls and abutments

Wingwall angle less than $90^{\circ}$.

19. Bridge Deck Comments (surface cover variations, measured bridge and span lengths, bridge type variations, approach overflow width, etc.)

Surface coverage on the right bank downstream is trees along banks (conifers) with a house and paved driveway $30 \mathrm{ft}$. from the channel. The measured bridge length was 30 feet, span length was 25 feet, and deck width was $23 \mathrm{ft}$. A road wash eroded gully is developing under the corner of the railing through holes in pavement and washing away material behind the downstream end of the right abutment.

\section{Upstream Channel Assessment}

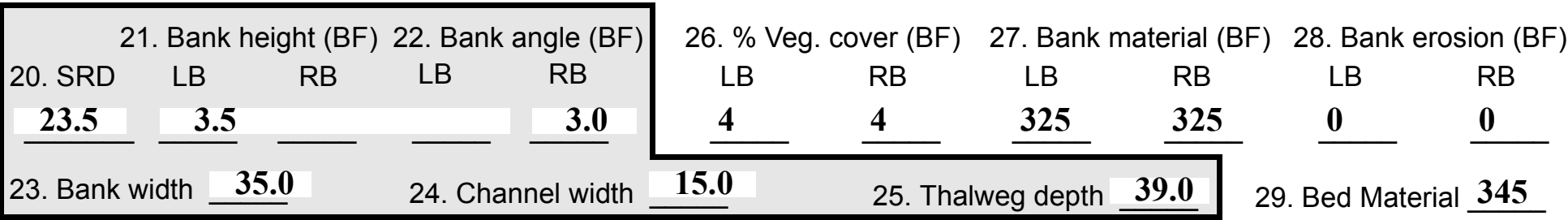

30 .Bank protection type: LB $\underline{\mathbf{0}}$

RB 0

31. Bank protection condition: LB $\mathrm{RB}$ -

SRD - Section ref. dist. to US face \% Vegetation (Veg) cover: 1- 0 to 25\%; 2- 26 to 50\%; 3- 51 to $75 \%$; 4- 76 to $100 \%$

Bed and bank Material: 0- organics; 1- silt / clay, <1/16mm; 2- sand, 1/16 - 2mm; 3- gravel, 2 - 64mm;

4- cobble, 64 - 256mm; 5- boulder, > 256mm; 6- bedrock; 7-manmade

Bank Erosion: 0- not evident; 1- light fluvial; 2- moderate fluvial; 3- heavy fluvial / mass wasting

Bank protection types: 0- absent; 1- < 12 inches; 2- < 36 inches; 3- < 48 inches; 4- < 60 inches; 5- wall / artificial levee

Bank protection conditions: 1-good; 2- slumped; 3- eroded; 4- failed

32. Comments (bank material variation, minor inflows, protection extent, etc.):

Bank material is gravel mixed with sand and some boulders along the right and left banks while the bed material is gravel with cobbles and some boulders. 
36. Point bar extent: 150 feet $\underline{\mathbf{U S}}$ (US, UB) to $\underline{\mathbf{2 5 0}}$ feet $\underline{\mathbf{U S}}$ (US, UB, DS) positioned $\underline{\mathbf{0}} \%$ LB to $\underline{\mathbf{6 0}} \%$ RB

37. Material: 423

38. Point or side bar comments (Circle Point or Side; Note additional bars, material variation, status, etc.):

This point bar is well developed but also is far away from influencing flow near the bridge. The predominant bar materials are gravel and sand with some cobbles.

39. Is a cut-bank present? $\mathbf{Y}$ ( $Y$ or if $N$ type ctrl-n $c b)$

40. Where? $\mathbf{R B}$ (LB or RB)

41. Mid-bank distance: $\mathbf{2 0 0}$

42. Cut bank extent: $\underline{\mathbf{1 5 0}}$ feet $\underline{\mathbf{U S}}$ (US, UB) to $\underline{\mathbf{2 4 0}}$ feet $\underline{\mathbf{U S}}$ (US, UB, DS)

43. Bank damage: 2

(1- eroded and/or creep; 2- slip failure; 3- block failure)

44. Cut bank comments (eg. additional cut banks, protection condition, etc.):

Cut bank is located along a power line right of way which has been cleared of large vegetation (trees).

45. Is channel scour present? $\mathbf{Y}$ ( $Y$ or if $N$ type ctrl-n cs) 46. Mid-scour distance: $\mathbf{2 0 0}$

47. Scour dimensions: Length $\underline{\mathbf{4 0}}$ Width $\underline{8}$ Depth : $\underline{\mathbf{1 . 5}}$ Position $\underline{\mathbf{1 0}} \%$ LB to $\underline{\mathbf{7 0}} \%$ RB

48. Scour comments (eg. additional scour areas, local scouring process, etc.):

Local scouring process due to a sharp channel bend within the cut bank zone.
49. Are there major confluences? $\mathbf{N}$
(Y or if $N$ type ctrl-n mc)
50. How many? -
51. Confluence 1: Distance -
Confluence 2: Distance -
52. Enters on -
Enters on - ( $L B$ or $R B)$ (LB or $R B)$
53. Type- (1-perennial; 2- ephemeral)
Type - (1-perennial; 2-ephemeral)

54. Confluence comments (eg. confluence name):

NO MAJOR CONFLUENCES

\section{Under Bridge Channel Assessment}

55. Channel restraint (BF)? LB 2

56. Height (BF)
LB RB
$\mathbf{2 1 . 0}-$
58. Bank width (BF) =-

59. Channel width (Amb) -

(1- natural bank; 2- abutment; 3- artificial levee)

Bed and bank Material: 0- organics; 1- silt / clay, < 1/16mm; 2- sand, 1/16 - 2mm; 3- gravel, 2 - 64mm; 4- cobble, 64 - 256mm; 5- boulder, > 256mm; 6- bedrock; 7- manmade

Bank Erosion: 0- not evident; 1- light fluvial; 2- moderate fluvial; 3- heavy fluvial / mass wasting

64. Comments (bank material variation, minor inflows, protection extent, etc.):

345

Bed material is gravel with cobbles and some boulders. 
65. Debris and Ice Is there debris accumulation?

67. Debris Potential $\underline{3}$ (1- Low; 2- Moderate; 3- High)

69. Is there evidence of ice build-up? $\underline{2}(Y$ or $N)$

70. Debris and Ice Comments:

1

Moderate accumulation of debris near the bridge. Trees are on the banks and the channel through the upstream reach, which is locally unstable laterally and meandering. Historical form notes heavy debris accumulation. Debris capture is moderate due to high channel gradient and the span length only $64 \%$ of the upstream bank width.

\begin{tabular}{|l|c|c|c|c|c|c|c|c|}
\hline Abutments & $\begin{array}{c}\text { 71. Attack } \\
\angle \text { (BF) }\end{array}$ & $\begin{array}{c}\text { 72. Slope } \angle \\
\text { (Qmax) }\end{array}$ & $\begin{array}{c}\text { 73. Toe } \\
\text { loc. (BF) }\end{array}$ & $\begin{array}{c}\text { 74. Scour } \\
\text { Condition }\end{array}$ & $\begin{array}{c}75 . \text { Scour } \\
\text { depth }\end{array}$ & $\begin{array}{c}\text { 76. Exposure } \\
\text { depth }\end{array}$ & 77. Material & 78. Length \\
\hline LABUT & & - & $\mathbf{8 5}$ & $\mathbf{2}$ & $\mathbf{2}$ & $\mathbf{0}$ & $\mathbf{1}$ & $\mathbf{9 0 . 0}$ \\
\hline RABUT & $\mathbf{1}$ & $\mathbf{1 5}$ & $\mathbf{8 5}$ & & & $\mathbf{2}$ & $\mathbf{2}$ & $\mathbf{2 3 . 5}$ \\
\hline
\end{tabular}

Pushed: $L B$ or RB

Toe Location (Loc.): 0- even, 1- set back, 2- protrudes

Scour cond.: 0- not evident; 1- evident (comment); 2- footing exposed; 3-undermined footing; 4- piling exposed; 5- settled; 6- failed

Materials: 1- Concrete; 2- Stone masonry or drywall; 3- steel or metal; 4- wood

79. Abutment comments (eg. undermined penetration, unusual scour processes, debris, etc.):

0

1.5

1

The right abutment has a sub-footing in front of the "original" footing with the entire height and length of the "original" footing exposed. The top of the sub-footing is exposed at the streambed elevation along the upstream half of the right abutment wall. Scour under the bridge is due to constriction of flow through the opening. The scour holes indicated in the structural inspection report (VTAOT, 7/18/92) were not observed at the time of this assessment.

80. Wingwalls:

$$
\text { Exist? Material? Scour } \begin{aligned}
& \text { Scour Exposure } \\
& \text { Condition? }
\end{aligned} \text { depth? } \begin{array}{lll}
81 . \\
\text { Angle? }
\end{array}
$$

USLWW:

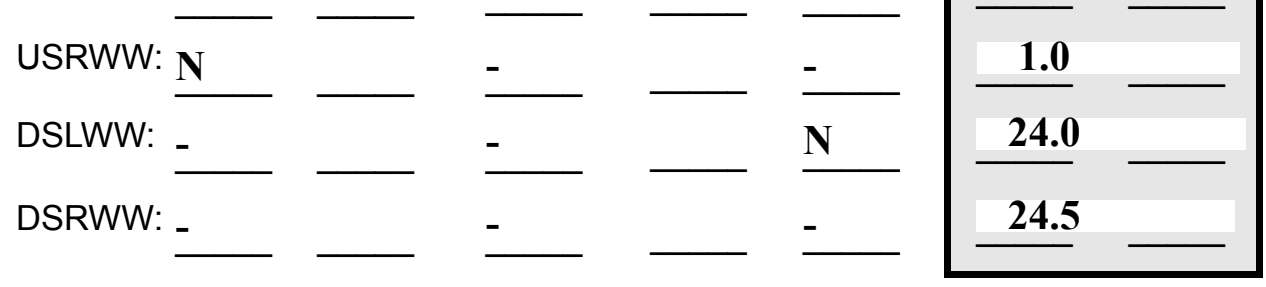

Wingwall materials: 1- Concrete; 2- Stone masonry or drywall; 3- steel or metal; 4- wood

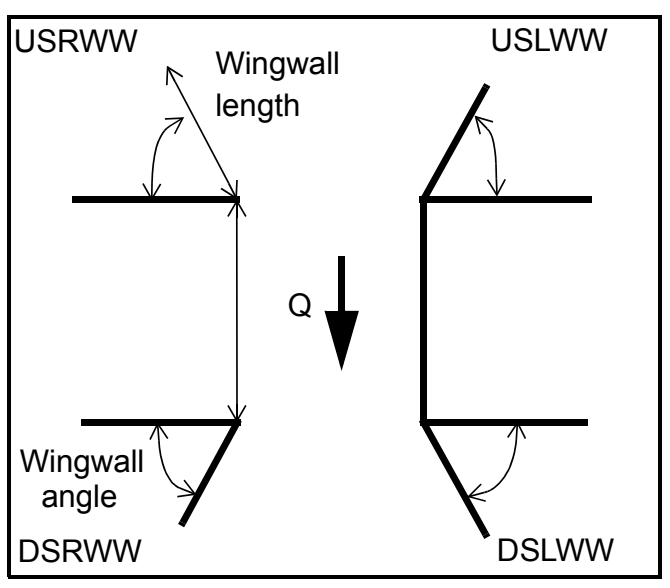

82. Bank / Bridge Protection:

\begin{tabular}{|l|l|l|l|l|l|l|l|l|}
\hline Location & USLWW & USRWW & LABUT & RABUT & LB & RB & DSLWW & DSRWW \\
\hline Type & - & - & N & - & - & - & - & - \\
\hline Condition & N & - & - & - & - & - & - & - \\
\hline Extent & - & - & - & - & - & - & - & - \\
\hline
\end{tabular}

Bank / Bridge protection types: 0- absent; 1- < 12 inches; 2- < 36 inches; 3- < 48 inches; 4- < 60 inches; 
83. Wingwall and protection comments (eg. undermined penetration, unusual scour processes, etc.):

-
-
-
-
-
-
-
-
-
-

\section{Piers:}

84. Are there piers? An (Y or if $N$ type ctrl-n pr)

\begin{tabular}{|l|l|l|l|l|l|l|l|}
\hline \multirow{2}{*}{$\begin{array}{l}85 . \\
\text { Pier no. }\end{array}$} & \multicolumn{3}{|c|}{ width (w) feet } & \multicolumn{3}{c|}{ elevation (e) feet } \\
\cline { 2 - 9 } & w1 & w2 & w3 & e@w1 & e@w2 & e@w3 \\
\hline Pier 1 & - & - & - & - & - & - \\
\hline Pier 2 & - & - & - & - & - & - \\
\hline Pier 3 & - & - & - & - & - & - \\
\hline Pier 4 & - & - & - & - & - & - \\
\hline
\end{tabular}

\begin{tabular}{|l|l|l|l|l|}
\hline Level 1 Pier Descr. & \multicolumn{1}{|c|}{1} & \multicolumn{1}{|c|}{2} & \multicolumn{1}{|c|}{3} & \multicolumn{1}{|c|}{} \\
\hline 86. Location (BF) & addi- & ream & the & d on \\
\hline 87. Type & tiona & right & sketc & the \\
\hline 88. Material & l & appr & h on & right \\
\hline 89. Shape & wall & oach & the & bank \\
\hline 90. Inclined? & and & to & field & dow \\
\hline 91. Attack $\angle$ (BF) & rail- & the & form & nstre \\
\hline 92. Pushed & ing & brid & ). & am \\
\hline 93. Length (feet) & - & - & - & - \\
\hline 94. \# of piles & were & ge & Boul & to \\
\hline 95. Cross-members & adde & (see & ders & pro- \\
\hline 96. Scour Condition & d to & phot & have & tect \\
\hline 97. Scour depth & the & o \#6 & been & the \\
\hline 98. Exposure depth & upst & and & place & bank \\
\hline
\end{tabular}

LFP, LTB, LB, MCL, MCM, MCR, RB, RTB, RFP

1- Solid pier, 2-column, 3- bent

1- Wood; 2- concrete; 3- metal; 4- stone

1- Round; 2- Square; 3- Pointed

Y-yes; $N$ - no

$L B$ or $R B$

0- none; 1- laterals; 2- diagonals; 3- both

0- not evident; 1- evident (comment);

2- footing exposed; 3- piling exposed;

4- undermined footing; 5- settled; 6- failed 
99. Pier comments (eg. undermined penetration, unusual scour processes, etc.): and private drive above.

$\mathbf{N}$

100.

\section{E. Downstream Channel Assessment}

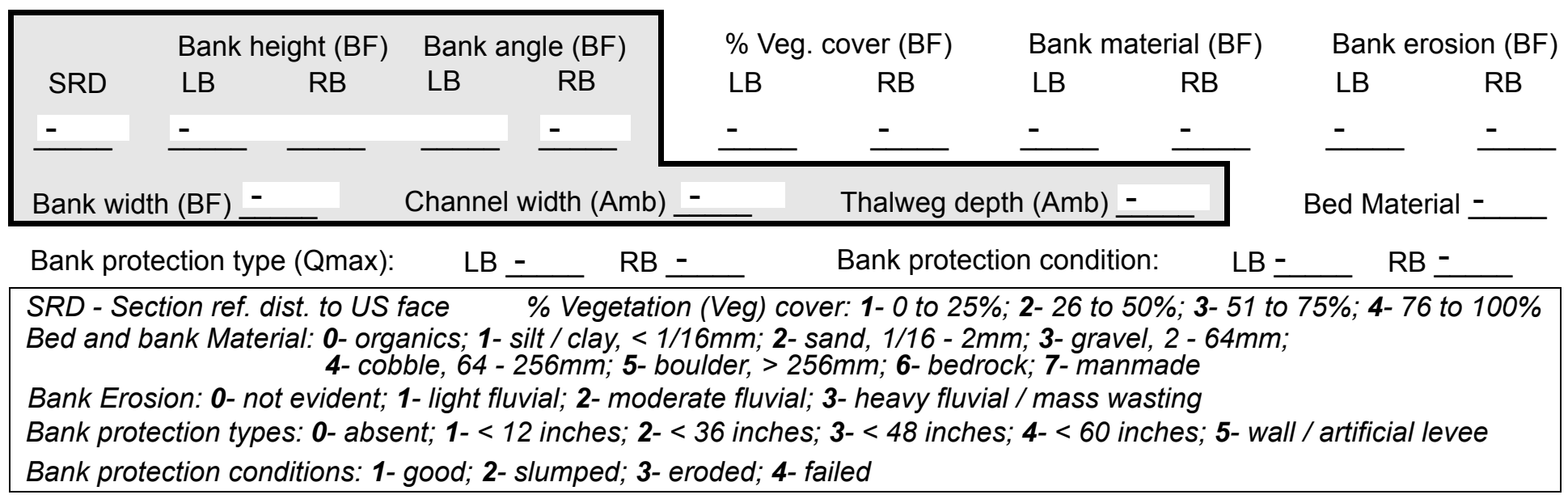

Comments (eg. bank material variation, minor inflows, protection extent, etc.):

$-$

$-$

-

$-$

$-$

$-$

$-$

$-$

$-$

$-$

$-$

$-$

$-$

$-$

$-$

101. Is a drop structure present? _ ( $Y$ or $N$, if $N$ type ctrl-n ds) 102. Distance: ___ feet 103. Drop: __ feet 104. Structure material: ___ (1- steel sheet pile; 2- wood pile; 3- concrete; 4- other) 105. Drop structure comments (eg. downstream scour depth):

$-$

-

$-$

-

- 
106. Point/Side bar present? (Y or $N$. if $N$ type ctrl-n pb)Mid-bar distance:

Mid-bar width: -

Point bar extent: feet -

(US, UB, DS) to feet (US, UB, DS) positioned $\%$ LB to $\% \mathrm{RB}$ Material:

Point or side bar comments (Circle Point or Side; note additional bars, material variation, status, etc.):

S a cut-bank present? $\mathbf{N}$ (Y or if $N$ type ctrl-n cb) Where? $\underline{\mathbf{O}}$ (LB or RB) Mid-bank distance: PIE Cut bank extent: $\underline{\mathbf{R S}}$ feet ___ (US, UB, DS) to feet (US, UB, DS)

Bank damage: (1- eroded and/or creep; 2- slip failure; 3- block failure)

Cut bank comments (eg. additional cut banks, protection condition, etc.):

Is channel scour present? ( $Y$ or if $N$ type ctrl-n cs)

Mid-scour distance: 2 Scour dimensions: Length $\mathbf{2}$ Width 235 Depth: 125

Positioned 0 $\%$ LB to 3 $\% \mathrm{RB}$ Scour comments (eg. additional scour areas, local scouring process, etc.): 345

0

0

$-$

Are there major confluences? - (Yor if $N$ type ctrl- $n$ mc)

Confluence 1: Distance left

Confluence 2: Distance mate Enters on ban ( $L B$ or RB)

Enters on rial ( $L B$ or $R B)$
How many? The

Type $\underline{\mathbf{k}}$ (1- perennial; 2- ephemeral)

Type is (1- perennial; 2- ephemeral)

Confluence comments (eg. confluence name):

mostly sands with gravel and some boulders while that of the right bank is silt/ clay, as revealed at the impact zone/cut bank, with sand and some boulders. The bed material is gravel with cobbles and some boulders.

\section{F. Geomorphic Channel Assessment}

107. Stage of reach evolution
1- Constructed

2- Stable

3- Aggraded

4- Degraded

5- Laterally unstable

6- Vertically and laterally unstable 
108. Evolution comments (Channel evolution not considering bridge effects; See HEC-20, Figure 1 for geomorphic descriptors): 


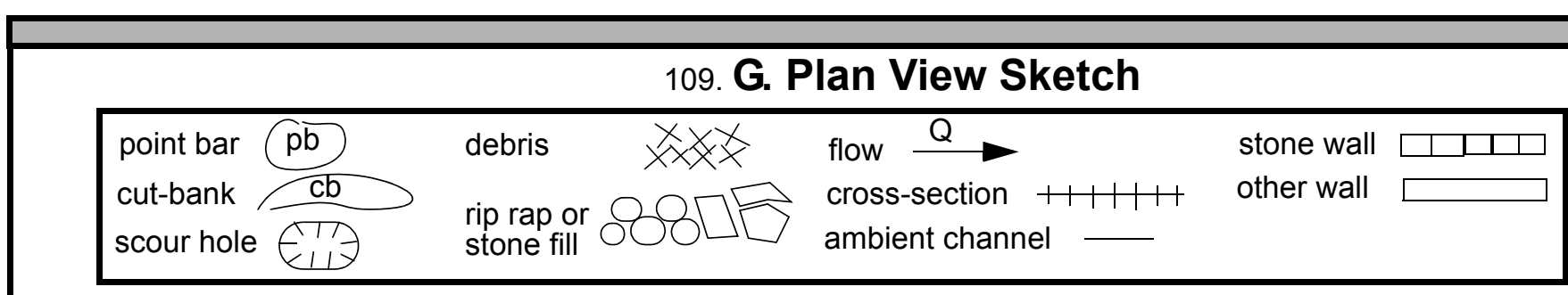


APPENDIX F:

SCOUR COMPUTATIONS 
SCOUR COMPUTATIONS

\begin{tabular}{|c|c|c|c|c|}
\hline Structure Number: BARTTH00020008 & & Town: & BARTON & \\
\hline Road Number: & & County: & ORLEANS & \\
\hline ROARING BROOK & & & & \\
\hline Initials EMB & Checked: & SAO & Date: & $4 / 15 / 96$ \\
\hline \multicolumn{5}{|c|}{ Analysis of contraction scour, live-bed or clear water? } \\
\hline \multicolumn{5}{|c|}{$\begin{array}{l}\text { Critical Velocity of Bed Material (converted to English units) } \\
\text { VC=11.21*y1^0.1667*D50^0.33 with } \mathrm{Ss}=2.65 \\
\text { (Richardson and others, } 1995, \mathrm{p} .28 \text {, eq. 16) }\end{array}$} \\
\hline \multicolumn{5}{|l|}{ Approach section } \\
\hline Characteristic & $100 \mathrm{yr}$ & $500 \mathrm{yr}$ & other $\mathrm{Q}$ & \\
\hline Total discharge, cfs & 1180 & 1730 & 0 & \\
\hline Main Channel Area, ft2 & 296.8 & 603.3 & 0 & \\
\hline Left overbank area, ft2 & 0 & 0 & 0 & \\
\hline Right overbank area, ft2 & 0 & 0 & 0 & \\
\hline Top width main channel, ft & 66.1 & 102.9 & 0 & \\
\hline Top width L overbank, ft & 0 & 0 & 0 & \\
\hline Top width $\mathrm{R}$ overbank, ft & 0 & 0 & 0 & \\
\hline D50 of channel, ft & 0.161 & 0.161 & 0.161 & \\
\hline D50 left overbank, ft & 0 & 0 & 0 & \\
\hline D50 right overbank, ft & 0 & 0 & 0 & \\
\hline $\mathrm{y}_{1}$, average depth, MC, ft & 4.5 & 5.9 & ERR & \\
\hline y1, average depth, LOB, ft & ERR & ERR & ERR & \\
\hline $\mathrm{y}^{1}$, average depth, ROB, ft & ERR & ERR & ERR & \\
\hline Total conveyance, approach & 21360 & 51977 & 0 & \\
\hline Conveyance, main channel & 21360 & 51977 & 0 & \\
\hline Conveyance, LOB & 0 & 0 & 0 & \\
\hline Conveyance, ROB & 0 & 0 & 0 & \\
\hline Percent discrepancy, conveyance & 0 & 0 & ERR & \\
\hline Qm, discharge, MC, cfs & 1180 & 1730 & ERR & \\
\hline Q1, discharge, LOB, cfs & 0 & 0 & ERR & \\
\hline Qr, discharge, ROB, cfs & 0 & 0 & ERR & \\
\hline $\mathrm{Vm}$, mean velocity $\mathrm{MC}$, ft/s & 4.0 & 2.9 & ERR & \\
\hline Vl, mean velocity, LOB, ft/s & ERR & ERR & ERR & \\
\hline Vr, mean velocity, ROB, ft/s & ERR & ERR & ERR & \\
\hline Vc-m, crit. velocity, $\mathrm{MC}$, ft/s & 7.8 & 8.2 & $\mathrm{~N} / \mathrm{A}$ & \\
\hline Vc-1, crit. velocity, LOB, ft/s & $\mathrm{N} / \mathrm{A}$ & $\mathrm{N} / \mathrm{A}$ & $\mathrm{N} / \mathrm{A}$ & \\
\hline Vc-r, crit. velocity, ROB, ft/s & $\mathrm{N} / \mathrm{A}$ & $\mathrm{N} / \mathrm{A}$ & $\mathrm{N} / \mathrm{A}$ & \\
\hline \multicolumn{5}{|l|}{ Results } \\
\hline \multirow{2}{*}{\multicolumn{5}{|c|}{$\begin{array}{c}\text { Live-bed(1) or Clear-Water }(0) \text { Contraction Scour } \\
\text { Main Channel }\end{array}$}} \\
\hline & & & & \\
\hline
\end{tabular}


Clear Water Contraction Scour in MAIN CHANNEL

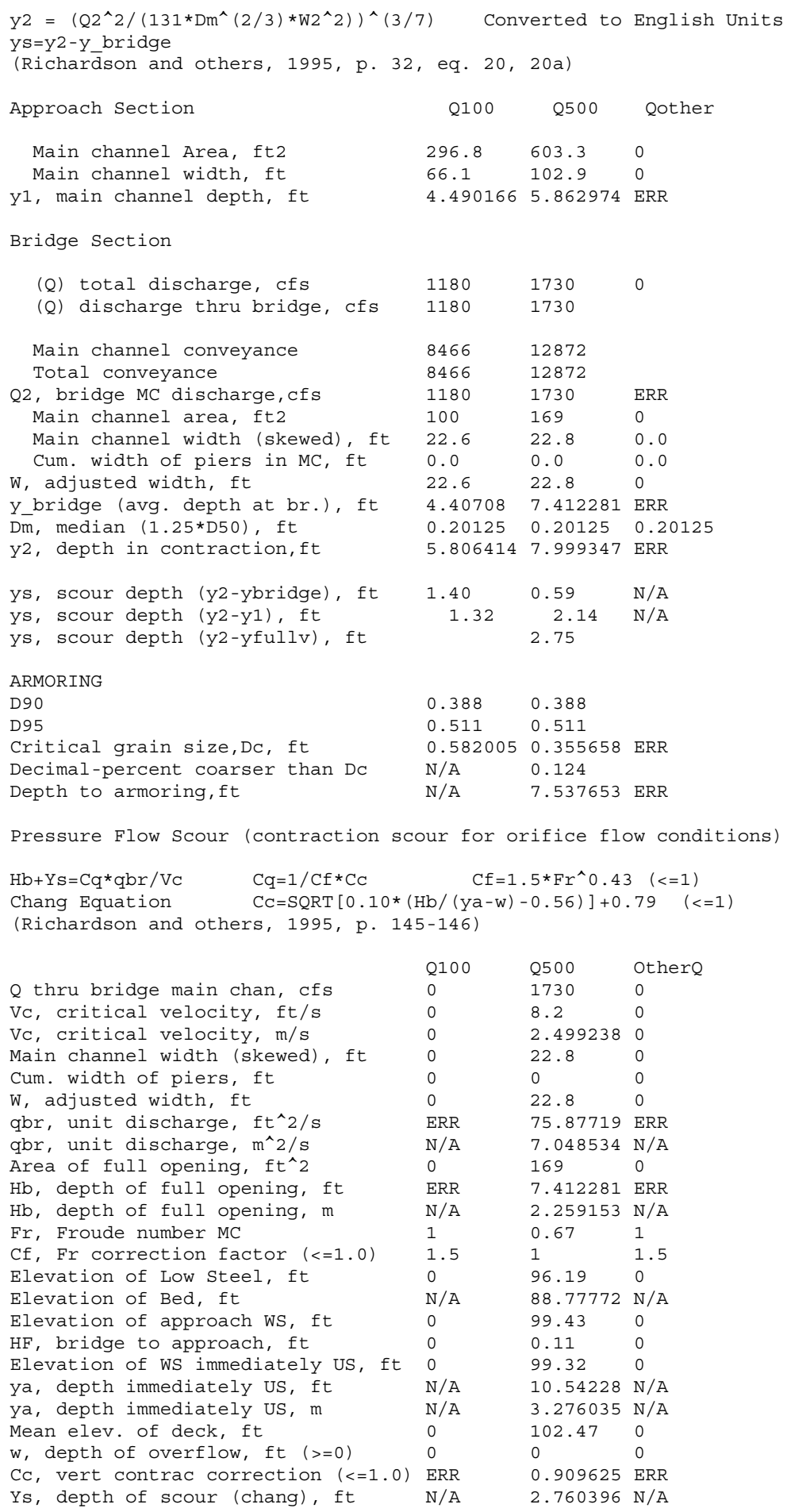




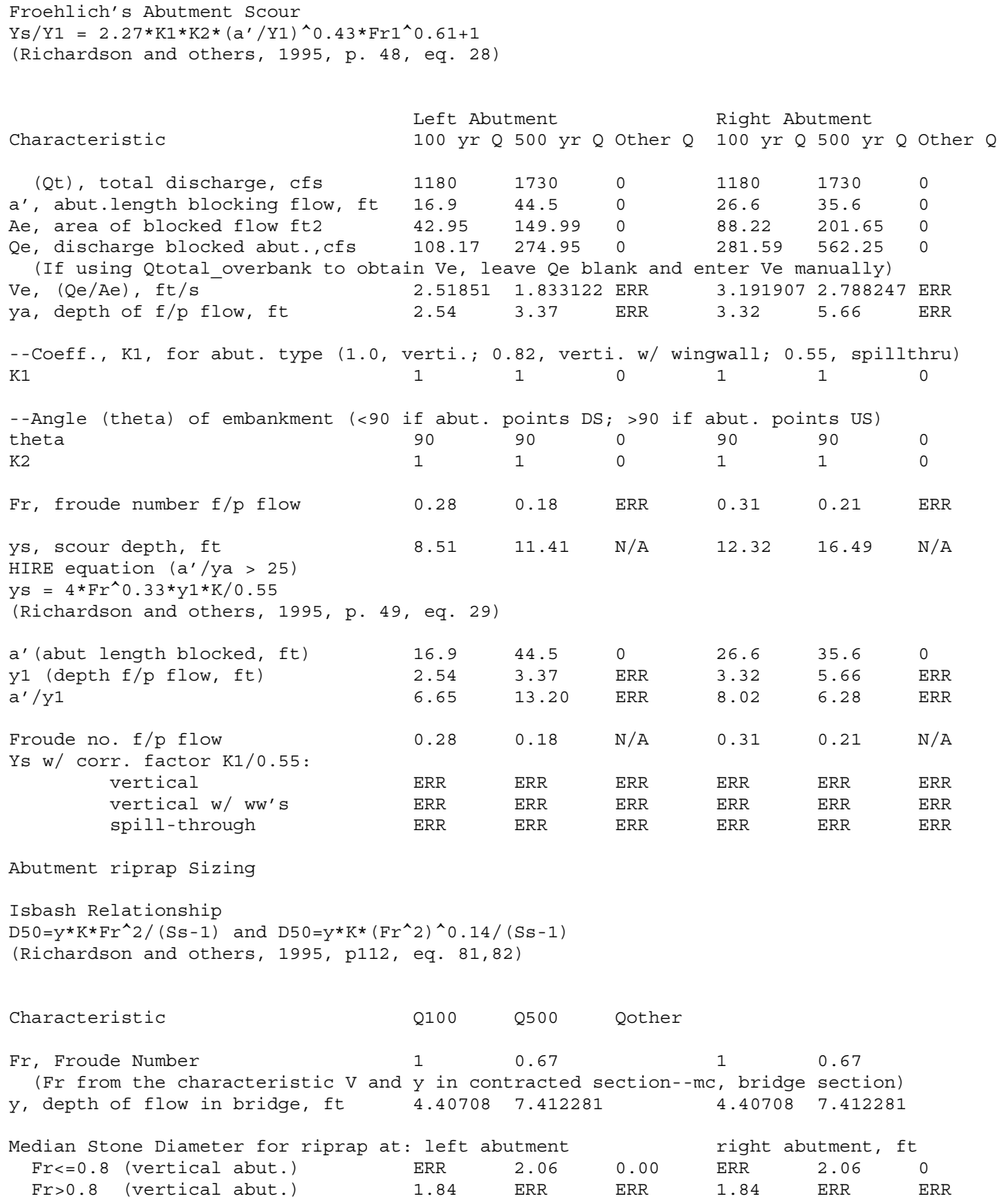

Abutment riprap Sizing

Isbash Relationship 